\title{
The upper Eocene-Oligocene carnivorous mammals from the Quercy Phosphorites (France) housed in Belgian collections
}

\author{
Floréal SOLÉ ${ }^{*}$, VAlENTIN FISCHER ${ }^{2}$, Julien DENAYER ${ }^{2}$, Robert P. SPEIJER ${ }^{3}$, MORGANe FOURNIER $^{4}$, Kévin $^{2}$
} LE VERGER $^{4}$, SANDRINE LADEVĖZE ${ }^{4}$, ANNELISE FOLIE ${ }^{5} \&$ THIERRY SMITH ${ }^{1}$

\begin{abstract}
${ }^{1}$ Directorate Earth and History of Life, Royal Belgian Institute of Natural Sciences, Rue Vautier 29, B-1000 Brussels, Belgium; floreal.sole@naturalsciences.be; thierry.smith@naturalsciences.be.

${ }^{2}$ Evolution \& Diversity Dynamics Lab, UR Geology, Université de Liège, Allée du 6 Aô̂t 14, B-4000 Liège, Belgium; v.fischer@uliege.be; julien.denayer@uliege.be.

${ }^{3}$ Department of Earth and Environmental Sciences, KU Leuven, Celestijnenlaan 200E, B-3001 Leuven, Belgium; robert.speijer@kuleuven.be.

${ }^{4}$ Centre de Recherche en Paléontologie - Paris (CR2P, UMR 7207) - CNRS/MNHN/Sorbonne Université - Muséum national d'Histoire naturelle, 57 rue Cuvier CP 38, F-75005 Paris, France; morgane.fournier@cri-paris.org; kevin.le-verger@edu.mnhn.fr; sandrine.ladeveze@mnhn.fr.

${ }^{5}$ Scientific Survey of Heritage, Royal Belgian Institute of Natural Sciences, Rue Vautier 29, B-1000 Brussels, Belgium; annelise.folie@naturalsciences.be.

*corresponding author.
\end{abstract}

ABSTRACT. The Quercy Phosphorites Formation in France is world famous for its Eocene to Miocene faunas, especially those from the upper Eocene to lower Oligocene, the richest of all. The latter particularly helped to understand the 'Grande Coupure', a dramatic faunal turnover event that occurred in Europe during the Eocene-Oligocene transition. Fossils from the Quercy Phosphorites were excavated from the middle $19^{\text {th }}$ century until the early $20^{\text {th }}$ century in a series of sites and became subsequently dispersed over several research institutions, while often losing the temporal and geographical information in the process. In this contribution, we provide an overview and reassess the taxonomy of these barely known collections housed in three Belgian institutions: the Université de Liège, KU Leuven, and the Royal Belgian Institute of Natural Sciences. We focus our efforts on the carnivorous mammals (Hyaenodonta and Carnivoramorpha) and assess the stratigraphic intervals covered by each collection. These fossils are derived from upper Eocene (Priabonian), lower Oligocene (Rupelian), and upper Oligocene (Chattian) deposits in the Quercy area. The richness of the three collections (e.g., the presence of numerous postcranial elements in the Liège collection), the presence of types and figured specimens in the Leuven collection, and some identified localities in the RBINS collection make these collections of great interest for further studies on systematics and the evolution of mammals around the 'Grande Coupure'.

KEYWORDS: Cynodictis, Europe, ‘Grande Coupure', Mammalia, Paleogene.

\section{Introduction}

The Quercy region (southwestern France; Fig. 1) contains many deposits with more than 80 distinct mammal localities that correspond to karstic fissure fillings. These paleokarst faunas range from the lower Eocene to the lower Miocene (Renaud et al., 1978; Rémy et al., 1987; Sigé et al., 1991; Legendre et al., 1992; Maitre et al., 2006, 2008; Escarguel et al., 2008; Maitre, 2014). This expanded temporal record, in addition to the quality and richness of the mammal fossils makes Quercy a key area for understanding the evolution of the European Paleogene mammals (Rémy et al., 1987; Legendre \& Hartenberger, 1992; Escarguel et al., 2008). However, from the beginning of the exploitation of the Quercy Phosphorites Formation in 1870 until its end in 1907, the exact sources of the fossils have rarely been recorded, and only toponyms were provided (e.g., Caylus, Lamandine, Bach). These names do not correspond to clearly defined fossiliferous sites, but that of close-by villages, resulting in occasional mixing of faunas of different ages. The fossils collected during that period make up for the so-called 'old Quercy collection' (see Rage, 2006: p.162; Maitre, 2014: p.143). However, since 1965, paleontologists from the Université des Sciences et Techniques du Languedoc at Montpellier (now part of the Université de Montpellier), the Université Paris 6 (former Université Pierre et Marie Curie, UMPC, now Sorbonne Université), the Université ClaudeBernard Lyon I, and later the Université of Poitiers with the support of the CNRS have exploited more precisely the rich fissure fillings of this area in order to provide a refined chronology of the deposits (Bonis et al., 1973; Rémy et al., 1987; Legendre \& Lévêque, 1997). This enabled characterization of the long-term evolution of the regional mammal fauna (Legendre \& Hartenberger, 1992; Escarguel \& Legendre, 2006; Escarguel et al., 2008).

The mammals from the Quercy area (Fig. 1) provide an excellent data source to analyze the dramatic faunal turnover that occurred during the 'Grande Coupure' (or 'Grande Coupure de Stehlin'), at the Eocene-Oligocene boundary (Stehlin, 1909; Legendre \& Marandat, 1986; Hartenberger, 1987; Legendre, 1989; Legendre \& Hartenberger, 1992;

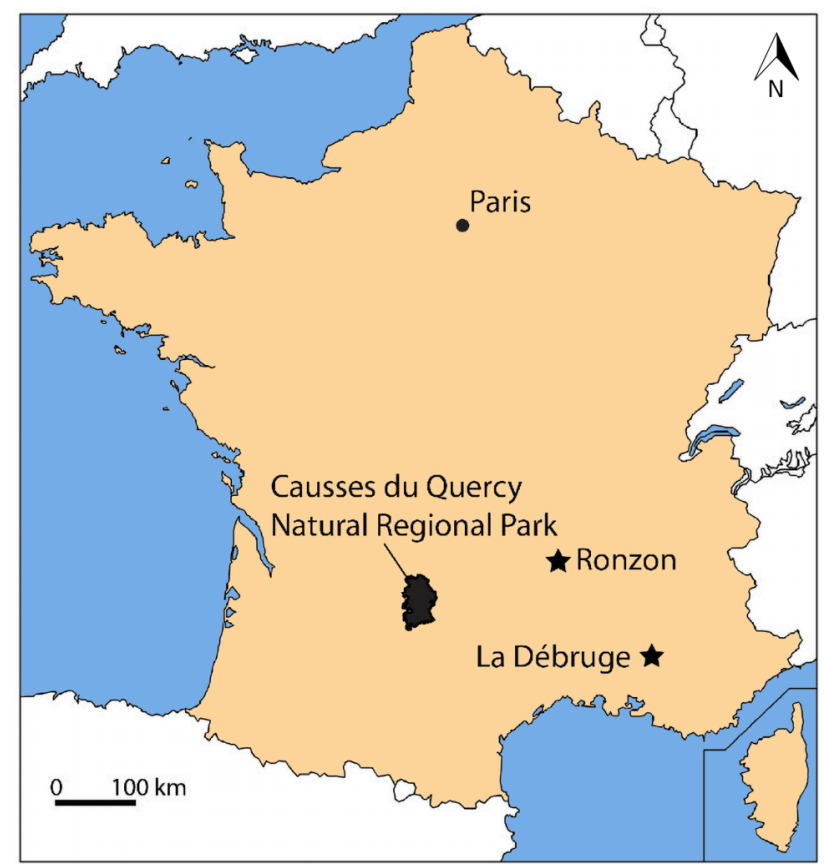

Figure 1. Location of the Quercy area (i.e. Causses du Quercy Natural Regional Park), and of the fossiliferous localities of La Débruge (MP18) and Ronzon (MP21). 
Escarguel et al., 2008). In western Europe, this turnover is characterized by an abrupt extinction event in mammal faunas during which about $60 \%$ of the existing lineages disappeared. This event also coincided with a major dispersal phase from Asia (Legendre, 1989; Legendre \& Hartenberger, 1992; Blondel, 2001; Escarguel \& Legendre, 2006; Escarguel et al., 2008; Maitre, 2014; Vianey-Liaud \& Marivaux, 2017).The 'Grande Coupure', which is related to intense and rapid global cooling (Zachos et al., 2001, 2008) strongly altered the meateating (i.e., carnivorous) mammal assemblages of Europe. Indeed, while hyaenodonts were the main predators in Europe during the entire Eocene (Solé et al., 2014a), they almost went extinct around the Eocene-Oligocene boundary (Lange-Badré, 1979), while carnivoramorphans, which were poorly diversified during the Eocene (Solé, 2014), suddenly became the dominant carnivorous mammals (Legendre et al., 1991).

A second key period in the history of the European carnivorous mammals is the late Chattian (ca. 24.8-23.03 Ma). This period corresponds to another major modification of the European carnivorous fauna, which is characterized by the appearance of the ailurids and of new and sometimes large-sized amphicyonid and ursidan genera (Springhorn, 1977; Morlo \& Peigné, 2010; Bonis, 2011, 2013). This event is probably related to the Late Oligocene Warming and subsequent dispersals ('Microbunodon Event'; see Scherler et al., 2013; Mennecart, 2015).

In the framework of an analysis of the evolution of carnivorous mammal clades over the course of the Paleogene (66-23.03 Ma; Vandenberghe et al. 2012) in Europe, we studied the collections from the Quercy Phosphorites housed in three Belgian institutions: KU Leuven (formerly known as Katholieke Universiteit Leuven), Université de Liège (ULiège), and Royal Belgian Institute of Natural Sciences (RBINS). These Quercy collections are poorly known to the paleontological community. We also paid attention to two other French fossiliferous localities (Fig. 1) housed in these Belgian institutions-La Débruge (Saint-Saturnin-lès-Apt, Vaucluse, France; reference level MP18 of the mammalian biochronological scale for the European Paleogene, middle Priabonian) and Ronzon (Le-Puyen-Velay, Haute-Loire, France; MP21, lower Rupelian) (BiochroM'97, 1997) - because their mammal faunas have been correlated with faunas recorded in the Quercy Phosphorites.

The present paper aims (1) to provide a thorough and updated taxonomic assessment of the carnivorous faunas and (2) to clarify the stratigraphic context of these collections. We also highlight important novel data for the researchers interested in the evolution of the European mammals around the 'Grande Coupure'.

\section{Material \& Methods}

\subsection{Origin and content of the collection}

\subsubsection{Material housed at the ULiège}

Tracing the origin of fossils in this collection can be challenging as it consists of several distinct collections, each having its own numbering scheme. Moreover, most historical data on these collections have been lost, mainly during the world wars. However, we recovered the record of some fossils from the Quercy Phosphorites. A first set of 23 fossils was acquired by Professor Gustave Dewalque in the 1870s. This material was transferred to the paleontological collection in 1889 when Professor Julien Fraipont succeeded G. Dewalque. This is supported by a note from J. Fraipont in the catalogue: 'passé de la Géologie à la Paléontologie' (moved from Geology to Paleontology collections). The exact origin of these fossils remains however unknown as they are simply labelled 'Eocène-
Oligocène du Quercy'. A second set of 58 fossils, recorded in the catalogue in 1892, was purchased by J. Fraipont from the fossil trader Alexandre Struer in Paris for 700 French francs (ca. 1700 euros nowadays). These fossils are from Caylus (a locality from the Quercy area; often misspelled as 'Caylux') and La Débruge (MP18).

Most of the specimens are mandibles and maxillary fragments, isolated teeth (mostly canines), and a lot of postcranial elements: femora, calcanei, astragali, innominates, claws, phalanges, and humeri. A few partial skulls are also present. The fossils have been mainly grouped based on global similarity and have never been thoroughly studied; some of them were identified as carnivorans ('Carnivores'), probably copied from the seller's identifications.

\subsubsection{Material housed at KU Leuven}

The fossils housed in this collection have been collected and studied by Henri Filhol at the end of the $19^{\text {th }}$ century (Filhol, 1872 , 1876/1877, 1879/1880, 1881). The collection was purchased at the beginning of the $20^{\text {th }}$ century by the Leuven canon Professor Henry de Dorlodot.

Most of the Paleogene fossils housed in this institution are labelled as being from the 'Phosphorites du Quercy'. The fossils were determined by Filhol, who figured only one of these specimens (Amphicyon ambiguus, KUL.PLV544; Filhol, 1876/1877). Some fossils have been studied thereafter (Teilhard de Chardin, 1915; Springhorn, 1977; Lange-Badré, 1979); two fossils of amphicyonids and two fossils of hyaenodonts have the status of holotype, while some others have been figured, notably by Lange-Badré (1979) in her study of the hyaenodonts from the upper Eocene and Oligocene and Springhorn (1977) in his revision of some amphicyonids (see Figs 7-8). Two additional French localities outside the Quercy area but close in age to the Eocene-Oligocene boundary are also present in the KU Leuven collection: La Débruge (MP18) and Ronzon (MP21).

\subsubsection{Material housed at the Royal Belgian Institute of Natural Sciences}

This collection includes fossils that have no precise location (i.e. 'Phosphorites du Quercy'), but also fossils from two identified fissure fillings-Roqueprune (MP23, Rupelian) and Pech du Fraysse (MP28, Chattian) - and from the locality of La Débruge (MP18, middle Priabonian). Four fissure fillings have been excavated in Roqueprune: Roqueprune 1, Roqueprune 2, Roqueprune 3, and Roqueprune 4; however, these fillings correspond to contemporary faunas (Rémy et al., 1987). We do not know from which fissure filling the fossils housed at the RBINS are.

The fossils lacking an exact location have been donated by Rossignol; they entered the collection of the RBINS on October $6^{\text {th }} 1947$ (Fig. 2A). The fossils from La Débruge, Roqueprune, and Pech du Fraysse have been collected by the amateur paleontologist Georges Wouters. They have been bought with the rest of the Wouters collections and entered the RBINS collections on December $19^{\text {th }} 1984$ (Fig. 2B).

The collection only comprises mandibles and maxillary fragments. Several fossils from the Rossignol's collection were identified, while the fossils from the Wouters' collection were simply referred to as 'carnivores'.

\subsection{Determination of the carnivoran taxa and their stratigraphic context}

We built a dataset that incorporates all carnivoramorphans, hyaenodonts, viverravids, and oxyaenids from the Paleogene of Europe that have been found in a locality that can be assigned to a MP reference level (Schmidt-Kittler et al., 1987; BiochroM'97, 1997) and that are identifiable at the specific 
A

1947

\begin{tabular}{|c|c|c|c|c|c|}
\hline $\begin{array}{c}\text { No } \\
\text { d'ordre } \\
- \\
\text { Volg- } \\
\text { nummer }\end{array}$ & $\begin{array}{c}\text { DATE } \\
\text { DE } \\
\text { LA RECEPTION } \\
- \\
\text { DATUM } \\
\text { DER } \\
\text { ONTVANGST }\end{array}$ & $\begin{array}{c}\text { DÉSIGNATION DES OBJETS } \\
- \\
\text { AANDUIDING } \\
\text { DER VOORWERPEN }\end{array}$ & $\begin{array}{c}\text { NOM } \\
\text { DU DONATEUR } \\
\text { OU } \\
\text { DU FOURNISSEUR } \\
- \\
\text { NAAM } \\
\text { VAN DEN SCHENKER } \\
\text { OF } \\
\text { L.EVERANCIER }\end{array}$ & $\begin{array}{l}\text { PRIX } \\
- \\
\text { PRIIS }\end{array}$ & $\begin{array}{l}\text { OBSERVATIONS } \\
- \\
\text { AANMERKINGEN }\end{array}$ \\
\hline
\end{tabular}
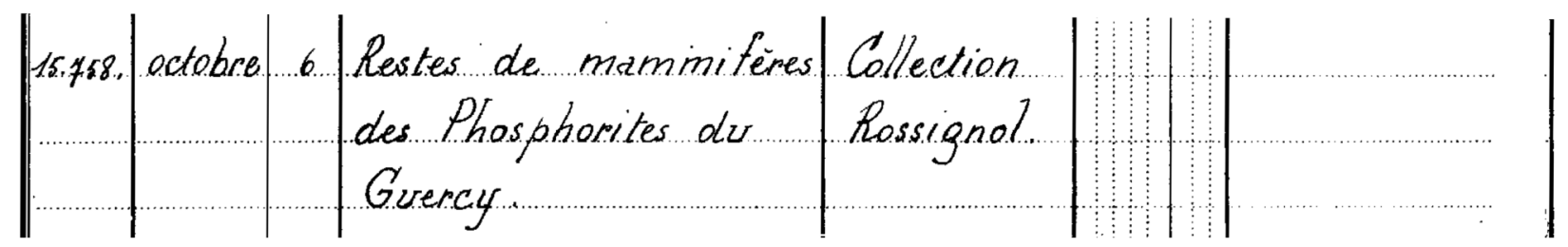

B

1984



Figure 2. Copy of the general inventory numbers catalogue of the RBINS with the entrance of Rossignol's collection (A) and Wouter's collection (B).

level. The MP reference levels included in this dataset are from MP6 (uppermost Thanetian, $\approx 57 \mathrm{Ma}$ ) to MP30 (uppermost Chattian, $\approx 23 \mathrm{Ma}$ ) and thus covers the time of deposition of the fossils from Quercy Phopshorites (MP10-MP30; Sigé et al., 1991; Legendre et al., 1992).

The fossils were determined using literature data and direct comparison with fossils housed at the Muséum National d'Histoire Naturelle (MNHN; Paris, France). Based on the determination of the fossils and their currently known stratigraphic ranges, the original stratigraphic range of each collection was reconstructed. It is worth mentioning that, because of their long biostratigraphic range, the majority of the species belonging to the genus Hyaenodon (Hyaenodonta) cannot be used for establishing stratigraphic contexts. See Supplementary data 1 for a list of the specimens from the three collections, their determination, their geographic origin, and the stratigraphic ranges of the taxa. 


\subsection{Determination of the tarsal bones}

While tooth-bearing elements are the main focus of this contribution, we provide a preliminary determination of the tarsal bones ( 84 astragali and 190 calcaneum) from the three Belgian collections and those of the MNHN. The material is determined at least at the familial level, using morphology, relative size, and relative abundance compared to that of the dental elements (Cifelli, 1983; Coillot et al., 2013). The majority of the specimens is from the 'Phosphorites du Quercy', but some housed in the collection of the MNHN have an exact origin: five are from La Débruge (MP18) and one from SainteNéboule (MP18).

The comparison of the body masses estimated based from dental and postcranial measurements can also be used to help systematic determinations. We used the equation of Tsubamoto (2014) $\left(\log (\mathrm{BM})=\left[3,125 \times \log ^{10}(\mathrm{La})\right]-0,463\right.$; with BM: the estimated body mass in $\mathrm{g}$; La: the maximum length of the astragalus in millimeters) to estimate the body mass based on astragalus, and those of Van Valkenburgh (1990) $\left(\log ^{10}(\mathrm{BM})=\right.$ $\left[2,97 \times \log ^{10}(\mathrm{Lm} 1)\right]-2,27$; with BM: the estimated body mass in $\mathrm{kg}$; Lm1: the length of the first lower molar in millimeters) and Morlo (1999) $\left(\log ^{10}(\mathrm{P})=\left[3.5104 \times \log ^{10}((\Sigma \mathrm{M}) / 3)\right]-\right.$ 2.6469; where $\mathrm{P}$ is the estimated body mass (in $\mathrm{g}$ ) and $\Sigma \mathrm{M}$ the sum of the length of the three lower molars in $\mathrm{mm}$ ) that are based on the size of selected teeth (data not shown here).

\subsection{The case of Cynodictis (Caniformia, Amphicyonidae)}

The amphicyonid Cynodictis appears highly variable in Belgian collections, both in size and in morphology. This genus is important because it is the oldest carnivoran that lived in Europe and it crossed the Eocene-Oligocene boundary (being present from MP18 to MP21 and possibly up to MP23; Kotsakis, 1980, p.268-269). However, the delimitation of the species included among Cynodictis is strongly debated, mainly because of the variability of the recognized species (Bravard \& Pomel, 1850; Filhol, 1876/1877; Teilhard de Chardin, 1915; Bonis, 1978; Kotsakis, 1980).

We performed a principal component analysis (PCA) in order to study the morphology of the lower molars of the Cynodictis and Cynodictis-like taxa determined from the Belgian collections and to identify criteria that allow the species to be discriminated from each other. Seven measurements were scored (p4 length, $\mathrm{p} 4$ width, $\mathrm{m} 1$ length, $\mathrm{m} 1$ width, $\mathrm{m} 2$ length, $\mathrm{m} 2$ width, and dentary depth (below $\mathrm{m} 1$ )) and estimated a series of ratios out of these measurements. Based on preliminary analyses, only three measurements and two ratios were kept $(\mathrm{m} 1$ length, $\mathrm{m} 1$ width, dentary depth, ratio length $\mathrm{m} 1 / \mathrm{m} 1$ width, ratio $\mathrm{m} 1$ length/dentary depth), in order to maximize the number of specimens used in the analysis. After this pruning, the dataset includes 52 specimens. The measurements and ratios are available in Supplementary data 2.

The PCA provides an overall analysis of the dataset by quantifying and analyzing the gross variability. This is done using conformation ratios (Mosimann \& James, 1979; Fabre et al., 2014). For each individual, size was computed as the geometric mean of all measurements, and each measurement was divided by size to obtain so-called shape ratios. Each ratio was then log-transformed (Claude, 2013), as size can indeed significantly affect integration (Porto et al., 2013). These logshape ratios allow to remove the isometric size from shape, and to explore only the conformation ratios as in geometric morphometrics (Fabre et al., 2014). All analyses were performed with a reduction of dimensionality (i.e. on the PCA axes). This allowed the possibility of choosing only a few variables by keeping the multivariate information and eliminating noise (Baylac \& Friess, 2005).

\subsection{Abbreviations}

Institutional: KUL.PLV, KU Leuven (Belgium), paleontological collection; MNHN.F.Qu, Muséum National d'Histoire Naturelle (Paris, France), fossil collection from the Quercy Phosphorites; RBINS Vert, Royal Belgian Institute of Natural Sciences (Brussels, Belgium), fossil vertebrates general collection; RBINS M, Royal Belgian Institute of Natural Sciences (Brussels, Belgium), fossil mammals type and figured specimens; ULg.PA, Université de Liège (Belgium), paleontological collection.

Other: n, number of specimens.

\section{Results}

\subsection{ULiège}

The taxa identified in the ULiège collections are listed in Table 1. Caniformians are clearly more abundant than feliformians (109 vs. 59 specimens; Supplementary data 1). This ratio thus parallels taxonomic diversity, as caniformians were far more speciose than feliformians within the lowermost Oligocene (MP21-MP22) and uppermost latest Oligocene (MP28-MP30) (Peigné, 2000). Among Caniformia, 64 fossils belong to Amphicyonidae and 34 to Ursida, which is not surprising since amphicyonids are the first (and sole) carnivorans recorded in the Priabonian, and their diversity increased during the late Chattian. Ursidans were also well diversified during the Oligocene, but mostly at the end of the Chattian, after the 'Microbunodon Event' (Bonis, 2011, 2013). Feliformians are represented by small aeluroids and nimravids; the latter were probably the main predators during the Rupelian (Peigné, 2000). We also identified hyaenodont taxa, including five species of Hyaenodon, one endemic hyaenodontoid (Paracynohyaenodon or Quercytherium), and one hyainailourine (Pterodon). Compared to the abundant Hyaenodon (119 specimens), the other hyaenodonts are rare. This abundance is not surprising because the genus was represented by eleven species that cover a large spectrum of sizes. Moreover, most of its species have a very long stratigraphic range, some spanning the Priabonian to upper Chattian (Lange-Badré, 1979).

The sole specimen from the ULiège paleontological collection that has a precise location is a mandible of Cynodictis lacustris lacustris (ULg.PA17399; Fig. 3E) from the Priabonian locality of La Débruge (MP18). Based on our determinations, we can split the whole collection into three main groups. Some fossils seem to come from Priabonian filling fissures; this is based on the presence of Pterodon (a hyainailourine restricted to MP18-MP20 interval; Fig. 3A-B) and of Hyaenodon requieni, Cynodictis lacustris lacustris, and C. lacustris intermedius (abundant in the Priabonian; Bonis, 1978) (Fig. 3C-D). The second group probably corresponds to a lower-middle Rupelian fauna (MP21-MP23) mainly based on the presence of the nimravids Eofelis, Eusmilus, and Nimravus (Fig. 4A-C), and the basal ursidan Amphicynodon (Fig. 4D-F). The third group corresponds to potential Chattian fossils. This assignment is supported by the presence of the ailurid Amphictis, the amphicyonid Cynelos, and the basal aeluroid Palaeoprionodon (Fig. 5).

\subsection{KU Leuven}

The taxa identified in the KU Leuven collection are listed in Table 2. Caniformians are more abundant than feliformians (Supplementary data 1). Surprisingly, this collection contains no nimravid and only small aeluroids. Ursidans are slightly more abundant than amphicyonids (24 vs. 18 specimens) and only three specimens of basal arctoids are identified. Hyaenodonts are well represented: 17 specimens belong to the persistent genus Hyaenodon; nine to endemic Eocene hyaenodontoids 
Table 1. Carnivorous mammal taxa identified in the collection of the ULiège and their known ranges. Note that the stratigraphic range of the taxon found at La Débruge corresponds to the MP level of the locality.

\begin{tabular}{|c|c|c|c|c|}
\hline Order & Species & Locality/Origin & $\begin{array}{l}\text { Stratigraphic } \\
\text { range (MP) }\end{array}$ & Stage \\
\hline Carnivora & Cynodictis lacustris & La Débruge & 18 & Priabonian \\
\hline Carnivora & Cynodictis intermedius & Phosphorites du Quercy & 18 & Priabonian \\
\hline Carnivora & Cynodictis lacustris & Phosphorites du Quercy & 18 & Priabonian \\
\hline Hyaenodonta & Hyaenodon requieni & Phosphorites du Quercy & $17-20$ & Priabonian \\
\hline Hyaenodonta & Paracynohyaenodon or Quercytherium & Phosphorites du Quercy & $16-17 \mathrm{a}$ or $16-18$ & Priabonian \\
\hline Hyaenodonta & Pterodon dasyuroides & Phosphorites du Quercy & $18-20$ & Priabonian \\
\hline Hyaenodonta & Hyaenodon gervaisi & Phosphorites du Quercy & $17 b-29$ & Priabonian-Oligocene \\
\hline Hyaenodonta & Hyaenodon sp. & Phosphorites du Quercy & $17-30$ & Priabonian-Oligocene \\
\hline Carnivora & Cynodictis longirostris & Phosphorites du Quercy & 18-21 (genus) & Priabonian-Rupelian \\
\hline Carnivora & Cynodictis exilis & Phosphorites du Quercy & 18-21 (genus) & Priabonian-Rupelian \\
\hline Carnivora & 'Cynodictis' palmidens & Phosphorites du Quercy & 21 & Rupelian \\
\hline Carnivora & Amphicynodon aff. crassirostris & Phosphorites du Quercy & 21-23 (genus) & Rupelian \\
\hline Carnivora & Amphicynodon sp. & Phosphorites du Quercy & 21-23 (genus) & Rupelian \\
\hline Carnivora & Amphicynodon aff. chardini & Phosphorites du Quercy & 21-23 (genus) & Rupelian \\
\hline Carnivora & Amphicynodon aff. leptorhynchus & Phosphorites du Quercy & $21-23$ & Rupelian \\
\hline Carnivora & Amphicynodon aff. typicus & Phosphorites du Quercy & $21-23$ & Rupelian \\
\hline Carnivora & Eofelis edwardsii & Phosphorites du Quercy & 22 & Rupelian \\
\hline Carnivora & Eusmilus bidentatus & Phosphorites du Quercy & $21-23$ & Rupelian \\
\hline Carnivora & Nimravus intermedius & Phosphorites du Quercy & $22-25$ & Rupelian \\
\hline Hyaenodonta & Hyaenodon dubius & Phosphorites du Quercy & $21-24$ & Rupelian \\
\hline Carnivora & Mustelictis aff. robustus & Phosphorites du Quercy & 25 & Rupelian/Chattian transition \\
\hline Carnivora & Adelpharctos ginsburgi? & Phosphorites du Quercy & 28 & Chattian \\
\hline Carnivora & Amphictis sp. & Phosphorites du Quercy & $28-30$ & Chattian \\
\hline Carnivora & Cynelos? & Phosphorites du Quercy & 26-30 (genus) & Chattian \\
\hline Carnivora & Cynelos aff. crassidens & Phosphorites du Quercy & $28-29$ & Chattian \\
\hline Carnivora & Cyonarctos sp. & Phosphorites du Quercy & 28 & Chattian \\
\hline Carnivora & Palaeoprionodon? & Phosphorites du Quercy & 29 & Chattian \\
\hline Carnivora & Palaeoprionodon mutabilis & Phosphorites du Quercy & 29 & Chattian \\
\hline Carnivora & Plesictis? & Phosphorites du Quercy & $28-30$ & Chattian \\
\hline Carnivora & Plesictis aff. stenogalinus & Phosphorites du Quercy & 28 & Chattian \\
\hline Carnivora & Pachycynodon aff. filholi & Phosphorites du Quercy & 21-29 (genus) & Oligocene \\
\hline Carnivora & Peusodcyonopsis sp. & Phosphorites du Quercy & $21-29$ & Oligocene \\
\hline Carnivora & Stenoplesictis cailuxy & Phosphorites du Quercy & $23-28$ & Oligocene \\
\hline Hyaenodonta & Hyaenodon exiguus & Phosphorites du Quercy & $22-30$ & Oligocene \\
\hline Hyaenodonta & Hyaenodon leptorhynchus & Phosphorites du Quercy & $22-30$ & Oligocene \\
\hline Carnivora & Haplogale media & Phosphorites du Quercy & Unknown & Oligocene \\
\hline Carnivora & Cephalogale? & Phosphorites du Quercy & 21-30 (genus) & Oligocene \\
\hline Carnivora & Cephalogale sp.1 & Phosphorites du Quercy & $21-30$ & Oligocene \\
\hline Carnivora & Cephalogale sp. 2 & Phosphorites du Quercy & $21-30$ & Oligocene \\
\hline Carnivora & Cephalogale sp. 3 & Phosphorites du Quercy & $21-30$ & Oligocene \\
\hline
\end{tabular}




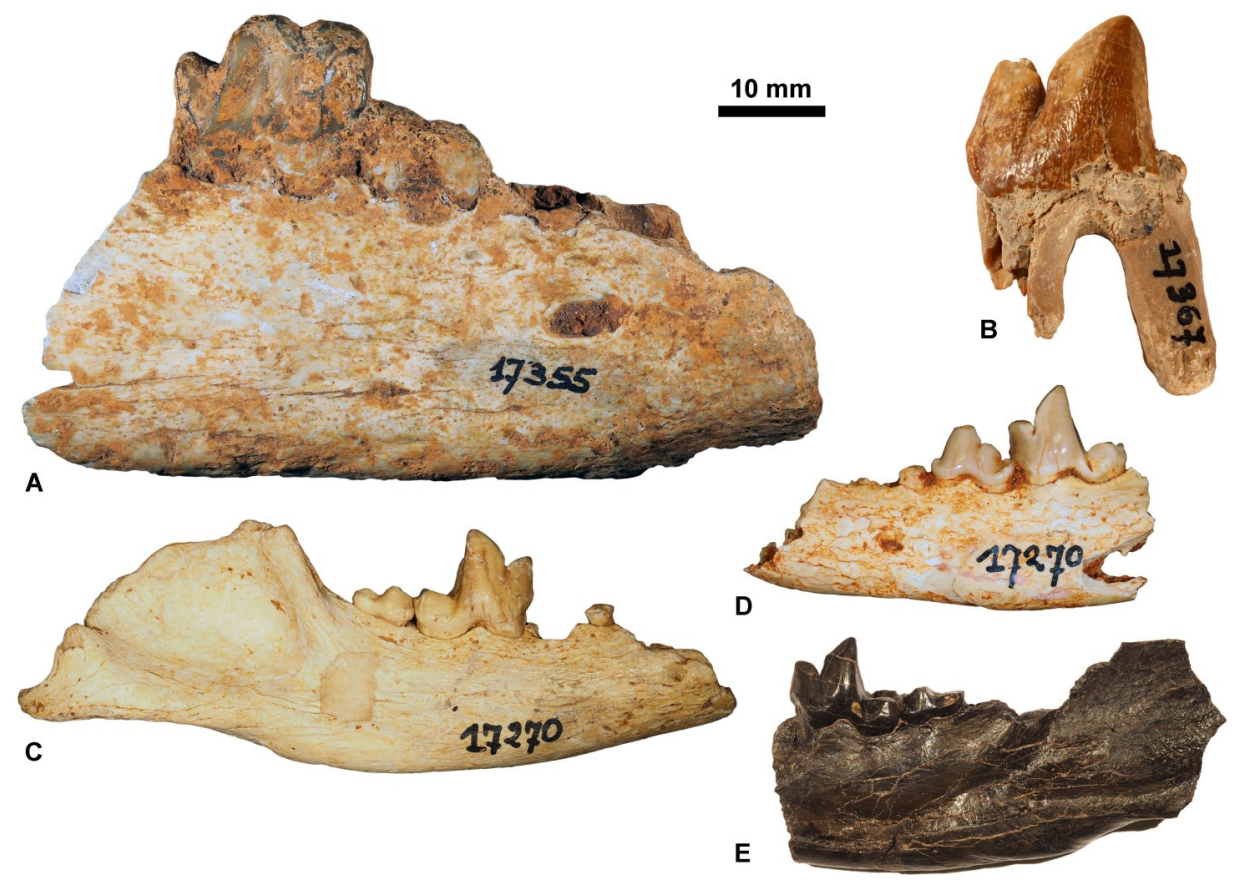

Figure 3. Priabonian carnivorous mammals housed at ULiège. A, Pterodon dasyuroides, ULg.PA.17355 (in labial view); B, Pterodon dasyuroides, ULg.PA.17367 (in labial view); $\mathrm{C}$, Cynodictis lacustris intermedius, ULg.PA.17270_1 (in labial view); D, Cynodictis lacustris lacustris, ULg.PA.17270 2 (in labial view); E, Cynodictis lacustris, from La Débruge (MP18), ULg.PA.17399 (in labial view).

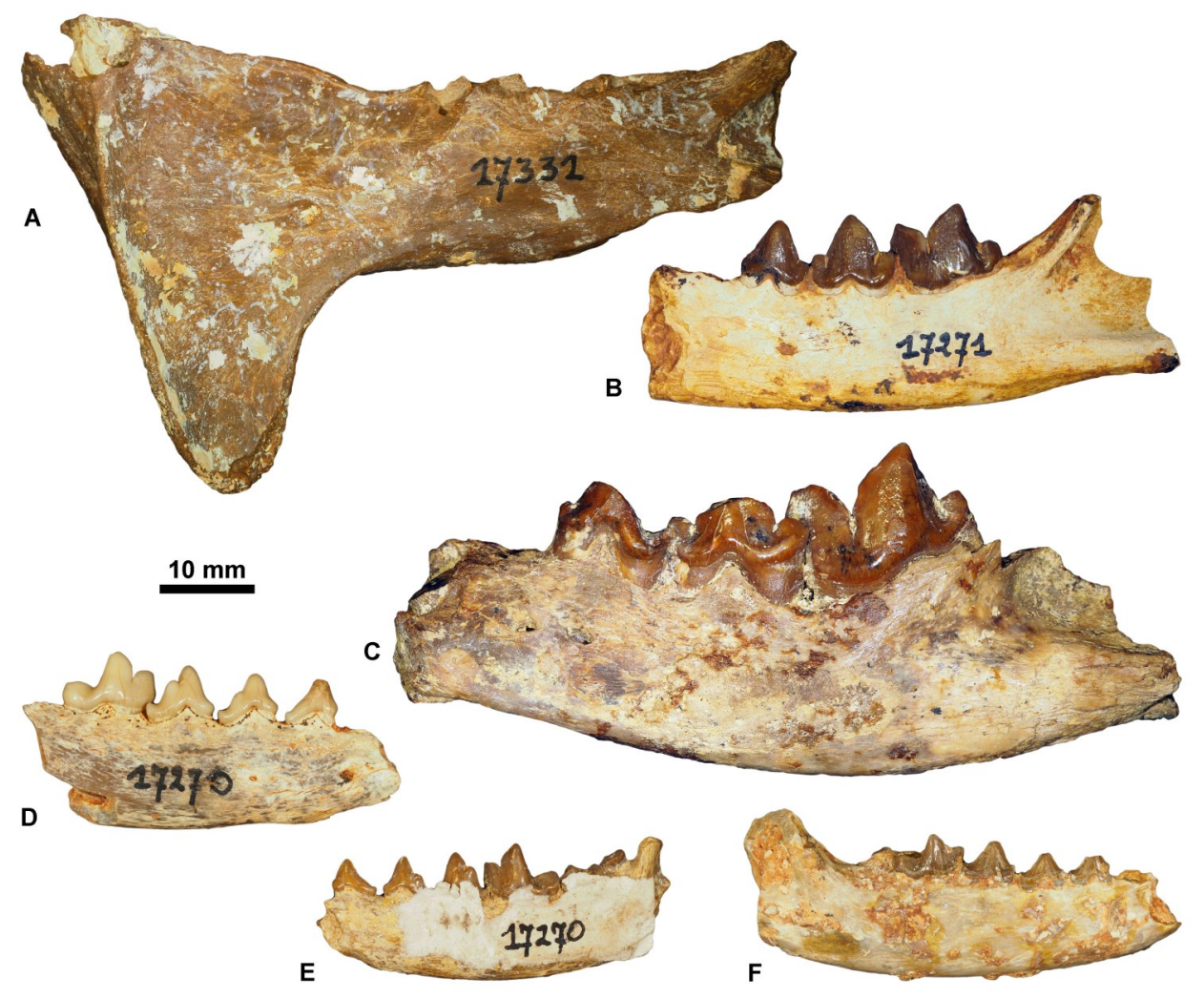

Figure 4. Rupelian carnivorous mammals housed at ULiège. A, Eusmilus bidentatus, ULg.PA. 17331 (in labial view); B, Eofelis edwardsii, ULg.PA.17271_1 (in labial view); C, Nimravus intermedius, ULg.PA.17271_2 (in labial view); D, Amphicynodon aff. typicus, ULg.PA.17270_3 (in labial view); E, Amphicynodon aff. chardini, ULg.PA.17270_4 (in labial view); F, Amphicynodon aff. leptorhynchus, ULg.PA. 17270_5 (in labial view).

(Cynohyaenodon and Quercytherium, both represented by casts; the original specimens are housed at the MNHN), and five to Pterodon. The presence of the enigmatic Thereutherium is of particular interest because this diminutive hyaenodont is rare and has a short stratigraphic range (MP23-MP26) (LangeBadré, 1995).

The combination of endemic hyaenodontoids (e.g., Cynohyaenodon and Quercytherium), the hyainailourine Pterodon (Fig. 6), and the amphicyonid Cynodictis lacustris intermedius and 'Cynodictis' compressidens indicates that some fossils of the KU Leuven collection come from Priabonian fissure fillings (MP17-MP20). The amphicyonid
Pseudocyonopsis antiquus, the ursidan Amphicynodon, the feliform Stenoplesictis minor, and the hyaenodont Thereutherium support a late Rupelian age (Fig. 7), probably around MP23-MP25 if they are derived from the same site. This late Rupelian age could explain the absence of nimravids, as well as the presence of Thereutherium. Indeed, the European nimravids rapidly decrease in diversity following MP22-MP23 (Peigné, 2000). Finally, the large amphicyonids Brachycyon and Haplocyon, the basal arctoidean Plesictis, and the feliform Palaeoprionodon indicate a late Chattian age for a part of the collection (Fig. 8). 

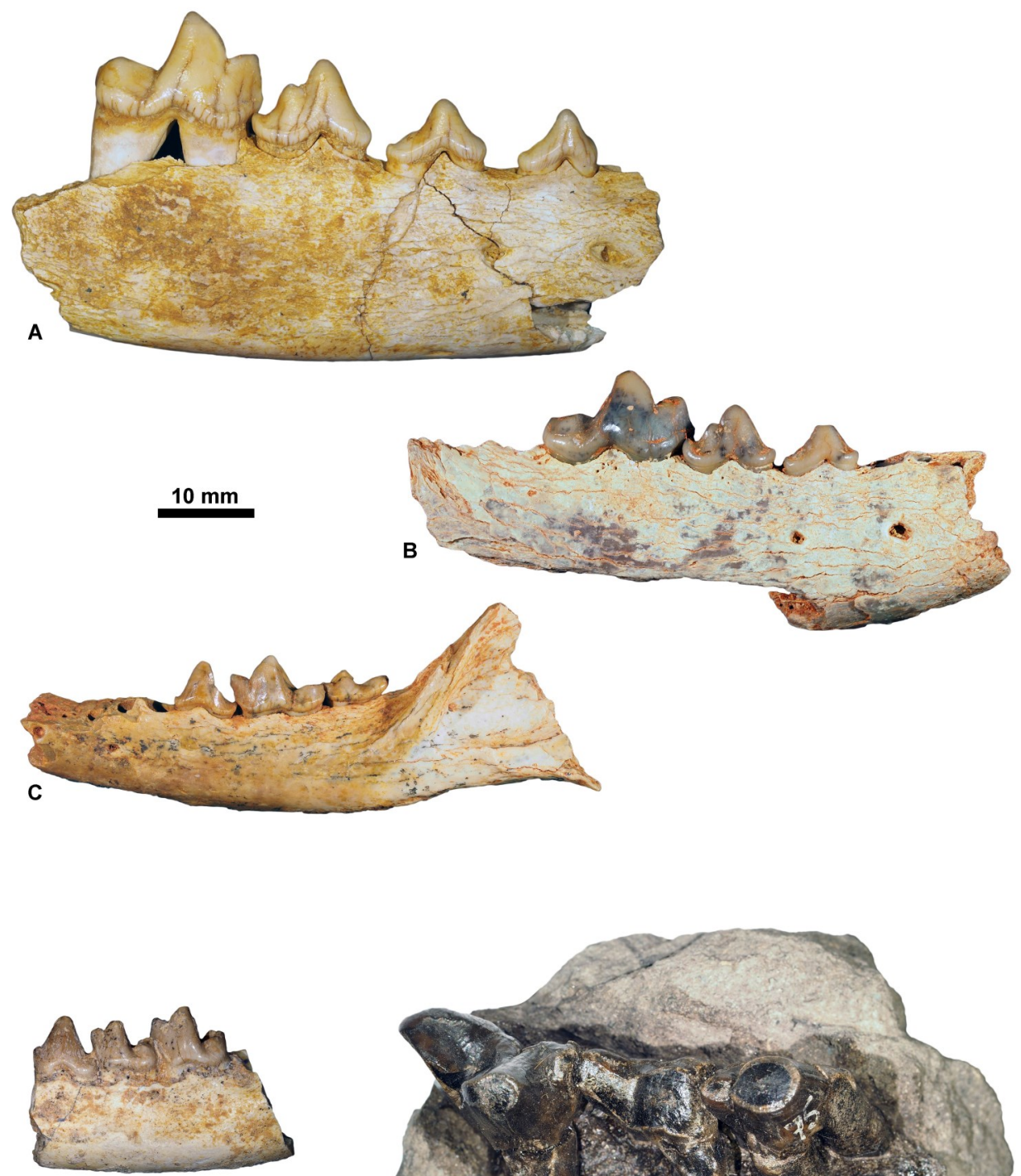

A

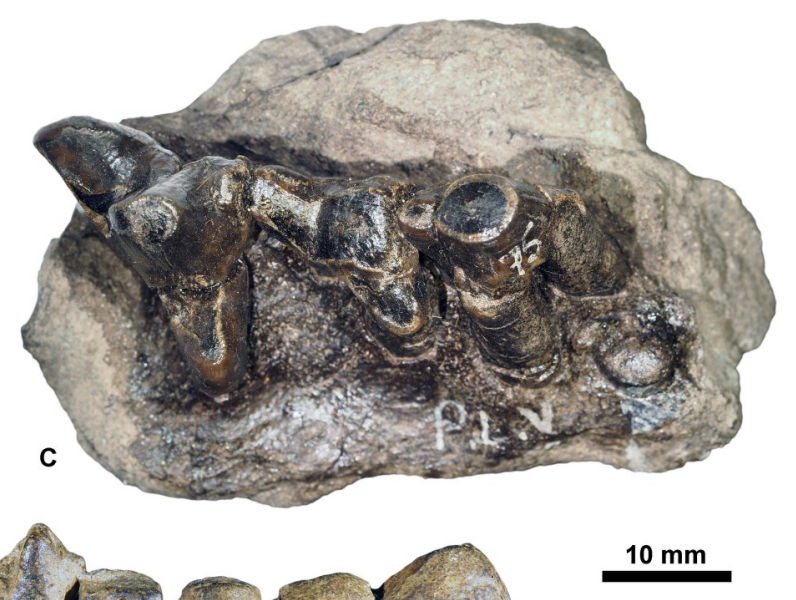

Figure 5. Chattian carnivorous mammals housed at ULiège. A, Cynelos aff. crassidens, ULg.PA.17270_6 (in labial view); B, Cephalogale sp.1, ULg.PA.17270_7 (in labial view); C, Amphictis sp., ULg.PA.17284 (in labial view).
Figure 6. Priabonian carnivorous mammals housed at $\mathrm{KU}$ Leuven. A, Cynohyaenodon cayluxi, KUL.PLV.70 (in labial view); B, Quercytherium tenebrosum, KUL.PLV.88 (cast of the Holotype, MNHN.F.Qu8644) (in labial view); C, Pterodon dasyuroides, KUL.PLV.75 (in occlusal view).

\section{3. $R B I N S$}

The taxa identified in the RBINS collections are listed in Table 3. The absence of endemic Eocene hyaenodontoid and the hyainailourine Pterodon in Rossignol's collection supports an Oligocene age for these faunas. This collection contains taxa that are generally restricted to the lower to middle Rupelian (MP21-MP23) such as Amphicynodon aff. typicus and Pachycynodon (Ursida), Nimravus (Nimravidae), and Hyaenodon dubius. The basal arctoidean Plesictis might have been found in upper Chattian fissure fillings (MP28-MP30).
The fossils from the Wouters' collection come from welldefined localities. The three carnivorous fossils from $\mathrm{La}$ Débruge (MP18) belong to Hyaenodon requieni. This agrees with the stratigraphic range of this species (MP17a-MP20). The fossils from Roqueprune (MP23) record the basal ursidan Amphicynodon, the aeluroids Stenoplesictis, and Hyaenodon exiguus, which indeed match the age of the locality. The locality of Pech du Fraysse (MP28) is richer than the two previous localities. The presence of the ursidans Phoberogale minor and Cyonarctos, the ailurid Amphictis, and two species of 
Table 2. Carnivorous mammal taxa identified in the collection of the KU Leuven and their known ranges. Note that the stratigraphic ran ges of the taxon found at La Débruge and Ronzon correspond to the MP level of the locality.

\begin{tabular}{|c|c|c|c|c|}
\hline Order & Species & Locality/Origin & Stratigraphic range (MP) & Stage \\
\hline Hyaenodonta & Hyaenodon requieni & La Débruge & 18 & Priabonian \\
\hline Hyaenodonta & Hyaenodon sp. & Ronzon & 21 & Rupelian \\
\hline Hyaenodonta & Cynohyaenodon cayluxi & Phosphorites du Quercy & $16-17$ & Bartonian-Priabonian \\
\hline Carnivora & 'Cynodictis' compressidens & Phosphorites du Quercy & 19 & Priabonian \\
\hline Carnivora & Cynodictis intermedius & Phosphorites du Quercy & 18 & Priabonian \\
\hline Hyaenodonta & Pterodon dasyuroides & Phosphorites du Quercy & $18-20$ & Priabonian \\
\hline Hyaenodonta & Quercytherium tenebrosum & Phosphorites du Quercy & $16-17$ & Priabonian \\
\hline Hyaenodonta & Hyaenodon sp. & Phosphorites du Quercy & $17 a-30$ & Priabonian-Oligocene \\
\hline Carnivora & Cynodictis ferox & Phosphorites du Quercy & 18-21 (genus) & Priabonian-Rupelian \\
\hline Carnivora & Cynodictis longirostris & Phosphorites du Quercy & $18-21$ (genus) & Priabonian-Rupelian \\
\hline Carnivora & Cynodictis sp. & Phosphorites du Quercy & 18-21 (genus) & Priabonian-Rupelian \\
\hline Hyaenodonta & Hyaenodon brachyrhynchus? & Phosphorites du Quercy & $17-23$ & Priabonian-Rupelian \\
\hline Carnivora & 'Cynodictis' palmidens & Phosphorites du Quercy & 21 & Rupelian \\
\hline Carnivora & Amphicynodon brachyrostris? & Phosphorites du Quercy & 21-23 (genus) & Rupelian \\
\hline Carnivora & Amphicynodon leptorhynchus & Phosphorites du Quercy & 21-23 (genus) & Rupelian \\
\hline Carnivora & Amphicynodon typicus & Phosphorites du Quercy & $21-23$ & Rupelian \\
\hline Carnivora & Pseudocyonopsis antiquus & Phosphorites du Quercy & $21-23$ & Rupelian \\
\hline Carnivora & Stenoplesictis minor & Phosphorites du Quercy & $23-25$ & Rupelian \\
\hline Carnivora & Brachycyon gaudryi & Phosphorites du Quercy & $26-28$ & Chattian \\
\hline Carnivora & Haplocyon elegans & Phosphorites du Quercy & $29-30$ & Chattian \\
\hline Carnivora & Palaeoprinodon mutabilis & Phosphorites du Quercy & 29 & Chattian \\
\hline Carnivora & Plesictis aff. robustus & Phosphorites du Quercy & 28-30 (genus) & Chattian \\
\hline Carnivora & Plesictis stenogalinus & Phosphorites du Quercy & 28 & Chattian \\
\hline Carnivora & Phoberogale minor & Phosphorites du Quercy & $28-30$ & Chattian \\
\hline Carnivora & Pachycynodon boriei & Phosphorites du Quercy & $22-29$ & Oligocene \\
\hline Carnivora & Pachycynodon filholi & Phosphorites du Quercy & 21-29 (genus) & Oligocene \\
\hline Carnivora & Sarcocyon ferox & Phosphorites du Quercy & $23-26$ & Oligocene \\
\hline Carnivora & Stenoplesictis? & Phosphorites du Quercy & $23-28$ & Oligocene \\
\hline Carnivora & Stenoplesictis cayluxi & Phosphorites du Quercy & $23-28$ & Oligocene \\
\hline Hyaenodonta & Hyaenodon leptorhynchus & Phosphorites du Quercy & $22-30$ & Oligocene \\
\hline Hyaenodonta & Thereutherium thylacodes & Phosphorites du Quercy & $23-26$ & Oligocene \\
\hline
\end{tabular}
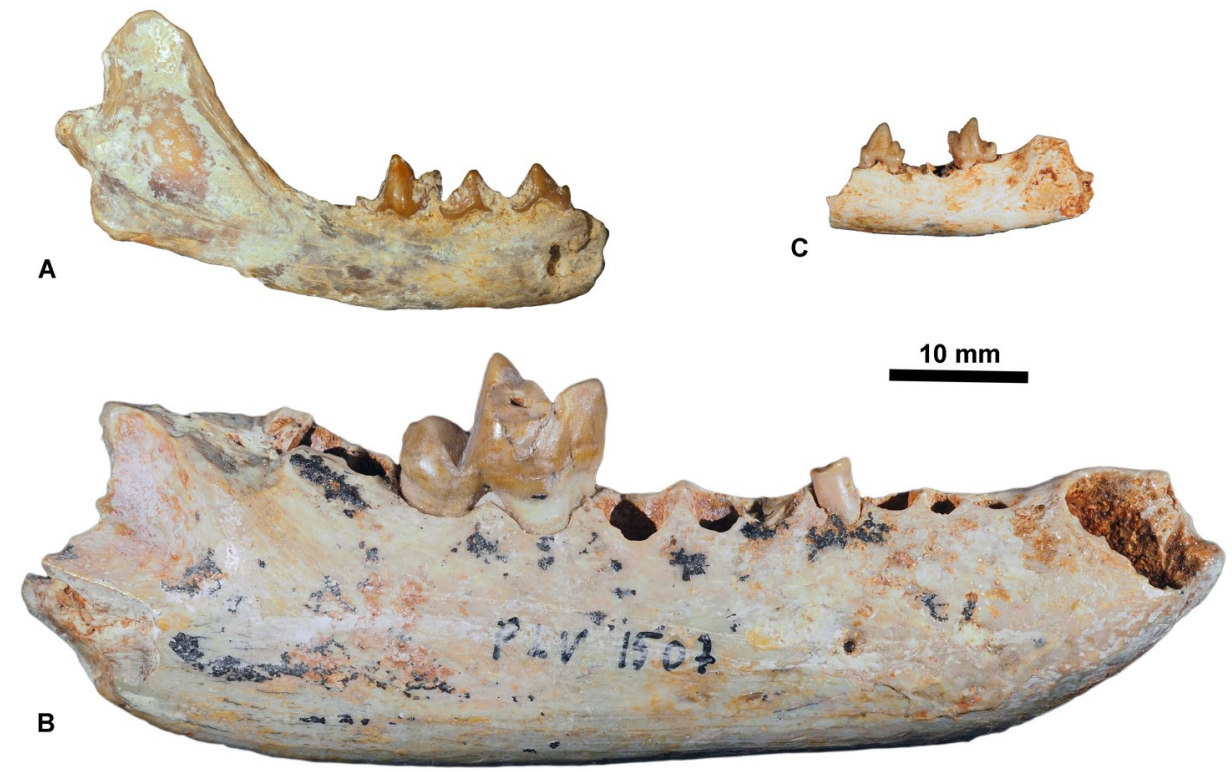

Figure 7. Rupelian carnivorous mammals housed at KU Leuven. A, Stenoplesictis minor, KUL.PLV1530 (in labial view); B, Pseudocyonopsis antiquus primigenius, KUL.PLV1507 (Holotype, specimen figured in Springhorn, 1977, fig. 21) (in labial view); C, Thereutherium thylacodes, KULPLVunnumbered (in labial view). 




A

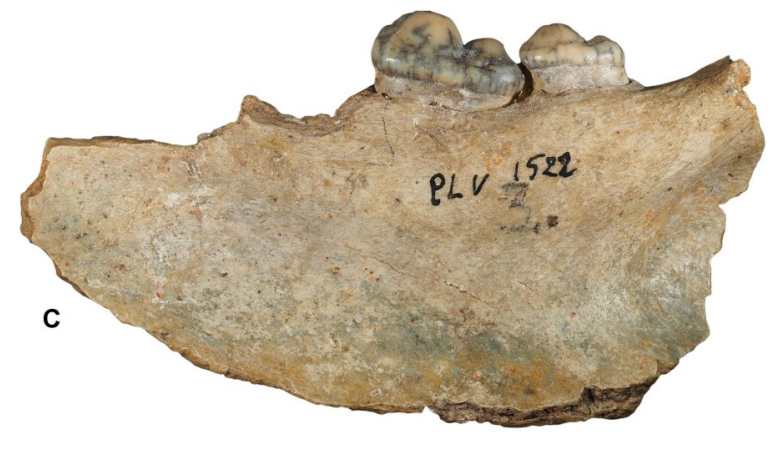

B
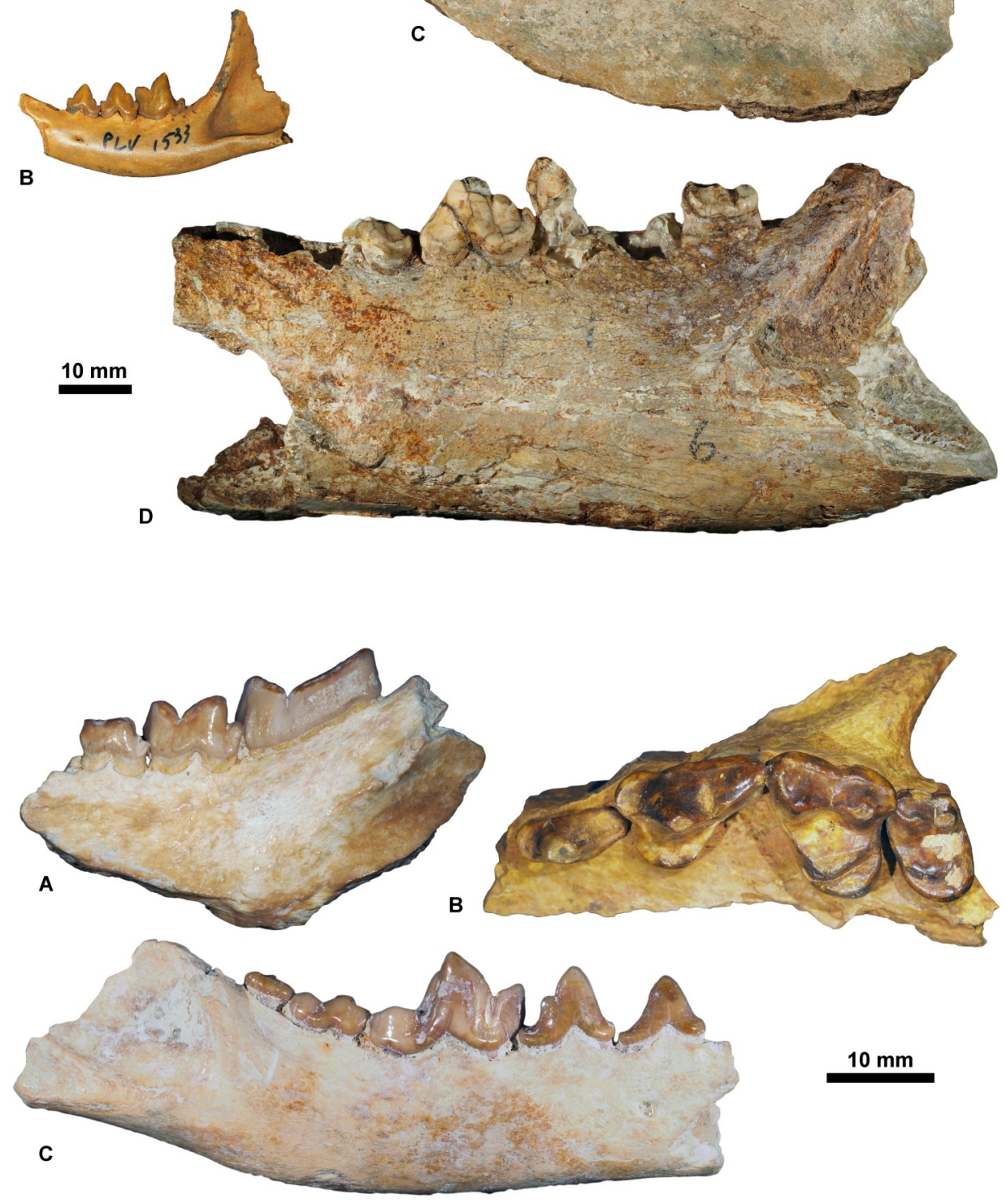

Figure 8. Chattian carnivorous mammals housed at KU Leuven. A, Haplocyon elegans, KUL. PLV1867 (specimen figured in Springhorn, 1977, fig. 71) (in occlusal view); B, Palaeoprionodon mutabilis, KUL.PLV1533 (in labial view); C, Sarcocyon ferox, KUL.PLV1522 (specimen figured in Springhorn, 1977, fig. 73) (in labial view); D, Brachcyon gaudryi, KUL.PLV1521 (specimen figured in Springhorn, 1977, fig. 44) (in labial view).
Figure 9. Carnivorous mammals from Pech du Fraysse (MP28) housed at the RBINS. A, Hyaenodon leptorhynchus, RBINS M 2326 (in labial view); B, Cyonarctos dessei, RBINS M 2327 (in occlusal view); C, Phoberogale minor, RBINS M 2328 (in labial view).
Stenoplesictis (S. crocheti and S. cayluxi) agrees with the late Chattian age of the fauna (Fig. 9).

\subsection{PCA of Cynodictis}

\section{Variance indeed reduced}

The first principal axis of our PCA explains $89.24 \%$ of the variance, while the second one explains $9.17 \%$ (Fig. 10B); these two axes thus summarize more than $98 \%$ of the variance of the dataset. While most taxa strongly overlap along the first axis, they are mainly separated by the second principal component, which is driven by $\mathrm{m} 1$ length and $\mathrm{m} 1$ width; it is worth keeping in mind that this axis accounts for only $9.17 \%$ of the variance. Despite the small variance expressed by the second axis, the distribution of groups in the morphospace with respect to this axis is in agreement with the descriptions of each species for which $C$. exilis and C. longirostris are quite distinct (Bonis, 1978) and C. intermedius and C. lacustris are extremely close, if not of the same group (Kotsakis, 1980). As visible on the morphospace, the species $C$. exilis is clearly dissociated from the other taxa. To a lesser extent, this is also the case for $C$. longirostris. However, this could result from the fact that these two taxa have a smaller sample compared to that of $C$. lacustris and $C$. longirostris. Interestingly, ' $C$.' palmidens is included in the region covered by C. longirostris (Fig. 10B).

\subsection{Tarsal bones}

Our analysis on the morphology of the tarsal elements (i.e., astragalus and calcaneum) allows to determine the presence of Hyaenodon, 'miacids', amphicyonids, ursidans, mustelids, and nimravids (Supplementary data 3; Fig. 11). The body mass estimated based on the astragali referred to the Nimravidae are close to those estimated (based on dental material) for the nimravid species Eusmilus bidentatus, Eusmilus villebramarensis, and Eofelis edwardsii (Table 4). The largest 
Table 3. Carnivorous mammal taxa identified in the collection of the RBINS and their known ranges. Note that the stratigraphic ranges of the taxon found at La Débruge, Roqueprune, and Pech du Fraysse correspond to the MP level of the locality.

\begin{tabular}{|c|c|c|c|c|}
\hline Order & Species & Locality/Origin & Stratigraphic range (MP) & Stage \\
\hline Hyaenodonta & Hyaenodon requieni & La Débruge & 18 & Priabonian \\
\hline Carnivora & Amphicynodon aff. typicus & Roqueprune & 23 & Rupelian \\
\hline Carnivora & Stenoplesictis aff cayluxi & Roqueprune & 23 & Rupelian \\
\hline Hyaenodonta & Hyaenodon aff. exiguus & Roqueprune & 23 & Rupelian \\
\hline Carnivora & Amphictis? & Pech du Fraysse & 28 & Chattian \\
\hline Carnivora & Amphictis ambigua? & Pech du Fraysse & 28 & Chattian \\
\hline Carnivora & Cyonarctos dessei & Pech du Fraysse & 28 & Chattian \\
\hline Carnivora & Phoberogale minor & Pech du Fraysse & 28 & Chattian \\
\hline Carnivora & Pseudocyonopsis? & Pech du Fraysse & 28 & Chattian \\
\hline Carnivora & Sarcocyon or Pseudocyonopsis & Pech du Fraysse & 28 & Chattian \\
\hline Carnivora & Stenoplesictis cayluxi & Pech du Fraysse & 28 & Chattian \\
\hline Carnivora & Stenoplesictis crocheti & Pech du Fraysse & 28 & Chattian \\
\hline Hyaenodonta & Hyaenodon leptorhynchus & Pech du Fraysse & 28 & Chattian \\
\hline Carnivora & Cynodictis lacustris? & Phosphorites du Quercy & 18 & Priabonian \\
\hline Hyaenodonta & Hyaenodon gervaisi & Phosphorites du Quercy & $17 b-29$ & Priabonian-Chattian \\
\hline Hyaenodonta & Hyaenodon leptorhynchus or H. minor & Phosphorites du Quercy & $22-30$ or $17 \mathrm{a}-18$ & Priabonian-Chattian \\
\hline Hyaenodonta & Hyaenodon sp. & Phosphorites du Quercy & $17 a-30$ & Priabonian-Chattian \\
\hline Hyaenodonta & Hyaenodon brachyrhynchus & Phosphorites du Quercy & $17 a-23$ & Priabonian-Rupelian \\
\hline Carnivora & Amphicynodon aff. typicus & Phosphorites du Quercy & $21-23$ & Rupelian \\
\hline Carnivora & Anictis? & Phosphorites du Quercy & 21 & Rupelian \\
\hline Carnivora & Nimravus intermedius & Phosphorites du Quercy & $22-25$ & Rupelian \\
\hline Carnivora & Pachycynodon aff. crassirostris & Phosphorites du Quercy & 22 & Rupelian \\
\hline Carnivora & Pachycynodon sp. & Phosphorites du Quercy & $21-22$ & Rupelian \\
\hline Hyaenodonta & Hyaenodon dubius? & Phosphorites du Quercy & $21-24$ & Rupelian \\
\hline Carnivora & Filholictis? & Phosphorites du Quercy & $?$ & Chattian \\
\hline Carnivora & Plesictis? & Phosphorites du Quercy & $28-30$ & Chattian \\
\hline Carnivora & Plesictis or Potamotherium & Phosphorites du Quercy & $28-30$ & Chattian \\
\hline Hyaenodonta & Hyaenodon exiguus & Phosphorites du Quercy & $22-30$ & Oligocene \\
\hline Hyaenodonta & Hyaenodon leptorhynchus & Phosphorites du Quercy & $22-30$ & Oligocene \\
\hline Carnivora & Cephalogale sp. 1 & Phosphorites du Quercy & $21-30$ & Oligocene \\
\hline Carnivora & Cephalogale sp. 2 & Phosphorites du Quercy & $21-30$ & Oligocene \\
\hline Carnivora & Cephalogale sp. 3 & Phosphorites du Quercy & $21-30$ & Oligocene \\
\hline Carnivora & Haplogale media & Phosphorites du Quercy & $?$ & Oligocene \\
\hline
\end{tabular}

astragali could represent Eusmilus individuals, while the smallest ones could correspond to Eofelis ones. Both Eofelis edwardsii and Eusmilus bidentatus are represented by dental elements in the ULiège collection (Table 1), but no dental element of nimravid is present in the KU Leuven collection.

Some tarsals that correspond to Hyaenodon have been found in the middle Priabonian (MP 18) sites of La Débruge and Sainte-Néboule (Supplementary data 3$)$. At that time ( $236 \mathrm{Ma})$, six Hyaenodon species are present in Europe: $H$. brachyrhynchus, $H$. gervaisi, $H$. heberti, $H$. requieni, and $H$. minor (Lange-Badré, 1979). The body masses estimated on these astragali range from 12 to $28 \mathrm{~kg}$ (Table 4). The lower limit of this range is close to the estimated body mass (based on dental material) of $H$. brachyrhynchus, while its upper limit is close to the body mass of $H$. heberti (Table 4). The four other species of Hyaenodon are either too light or too heavy to be considered as plausible reference for the studied specimens (Lange-Badré, 1979).
Several tarsal bones are referred to the paraphyletic assemblage 'Miacidae' (Supplementary data 3); these primitive carnivoraforms (Flynn et al., 2010) disappeared from Europe at the end of the Eocene. The astragali indicate body masses ranging from four to seven kilograms. Such a body mass is close to that estimated for Quercygale angustidens and much higher than those of Paramiacis and lower than those Simamphicyon (Table 4). However, the Belgian collections contain no specimens of Quercygale.

\section{Discussion}

\subsection{Biostratigraphic ranges of the Belgian collections from the Quercy Phosphorites}

Using faunal assemblages as a biostratigraphic tool helps clarifying the stratigraphic ranges of old Quercy collections. Even when an exact biostratigraphic context at the MP level cannot be reconstructed unambiguously, our analysis allows to 

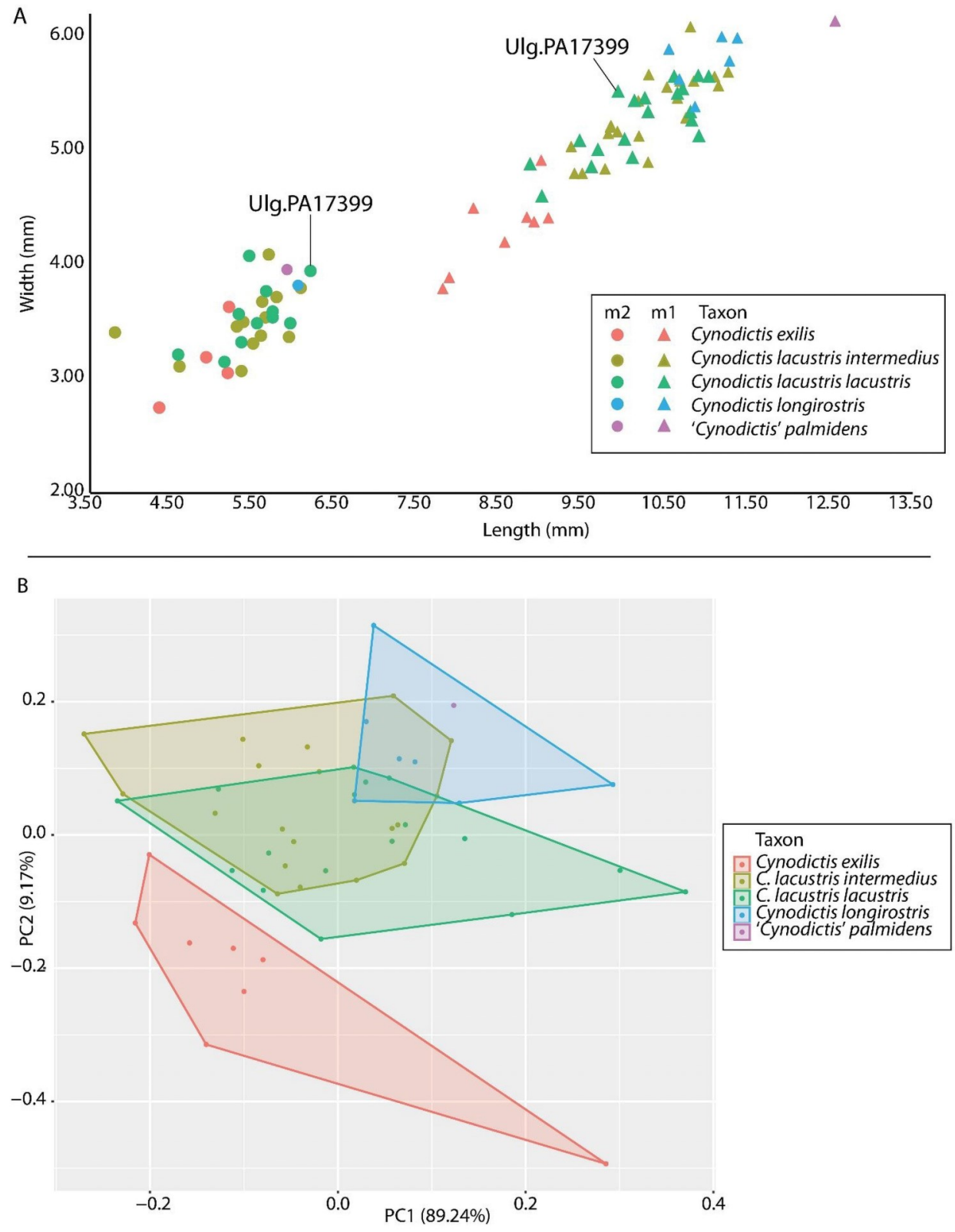

\begin{tabular}{lll}
\hline Taxon & Body mass (dental material) & Body mass (astragalus) \\
\hline $\begin{array}{l}\text { Hyaenodon } \\
\text { Hyaenodon brachyrhynchus }\end{array}$ & $4-50 \mathrm{~kg}$ & \\
$\begin{array}{l}\text { Hyaenodon gervaisi } \\
\text { Hyaenodon heberti }\end{array}$ & $50 \mathrm{~kg}$ & \\
$\begin{array}{l}\text { Hyaenodon minor } \\
\text { Hyaenodon requieni } \\
\text { Hyaenodon rossignoli }\end{array}$ & $31 \mathrm{~kg}$ & $12-28 \mathrm{~kg}$ \\
\hline Miacidae & $38 \mathrm{~kg}$ & \\
$\begin{array}{l}\text { Paramiacis } \\
\text { Quercygale angustidens }\end{array}$ & $4 \mathrm{~kg}$ & \\
Simamphicyon & $170 \mathrm{~g}-28 \mathrm{~kg}$ & \\
& $500-600 \mathrm{~g}$ & \\
Amphicyonidae & $28 \mathrm{~kg}$ & \\
\hline Mustelidae & $3-133 \mathrm{~kg}$ \\
\hline & $1-6 \mathrm{~kg}$ & \\
Nimravidae & & \\
Eofelis edwardsii & $9-98 \mathrm{~kg}$ & $228 \mathrm{~g}-1 \mathrm{~kg}$ \\
Eusmilus bidentatus & $9 \mathrm{~kg}$ & \\
Eusmilus villebramarensis & $22 \mathrm{~kg}$ & \\
\hline
\end{tabular}

Figure 10. A, Comparison of the sizes (length $\mathrm{x}$ width) of the $\mathrm{m} 1$ and $\mathrm{m} 2$ of specimens referred to Cynodictis and 'Cynodictis' palmidens with emphasizes on ULg.PA17399 (C. lacustris) from La Débruge (MP18). B, biplot of the first two components of the PCA.

Table 4. Comparison of the body masses estimated based on the dental material and the astragalus for the taxa identified based on the tarsal elements. 

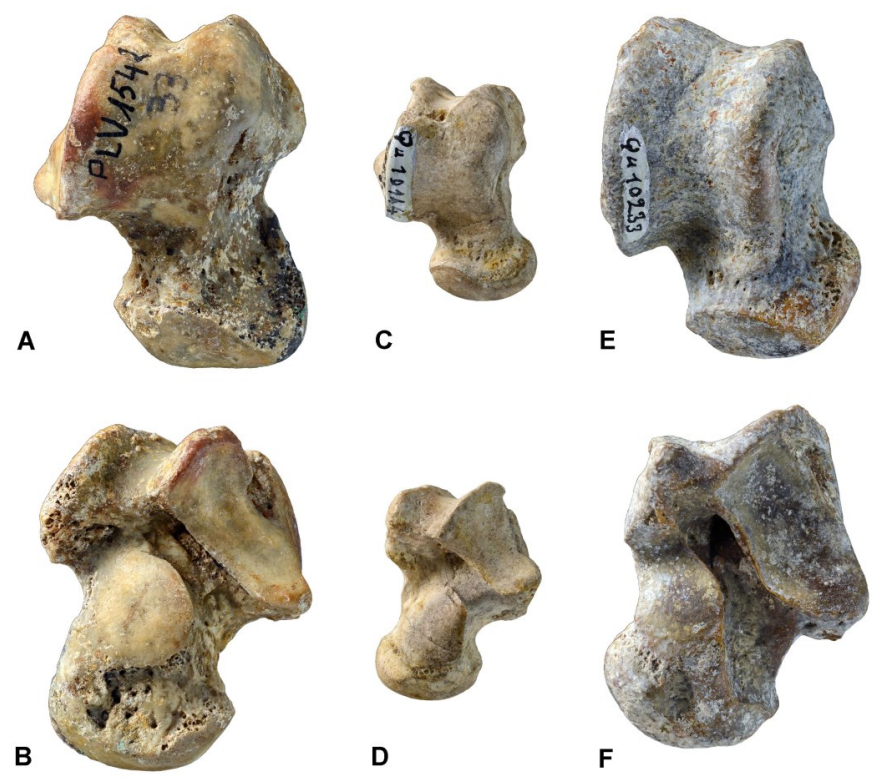

D



$\mathbf{F}$
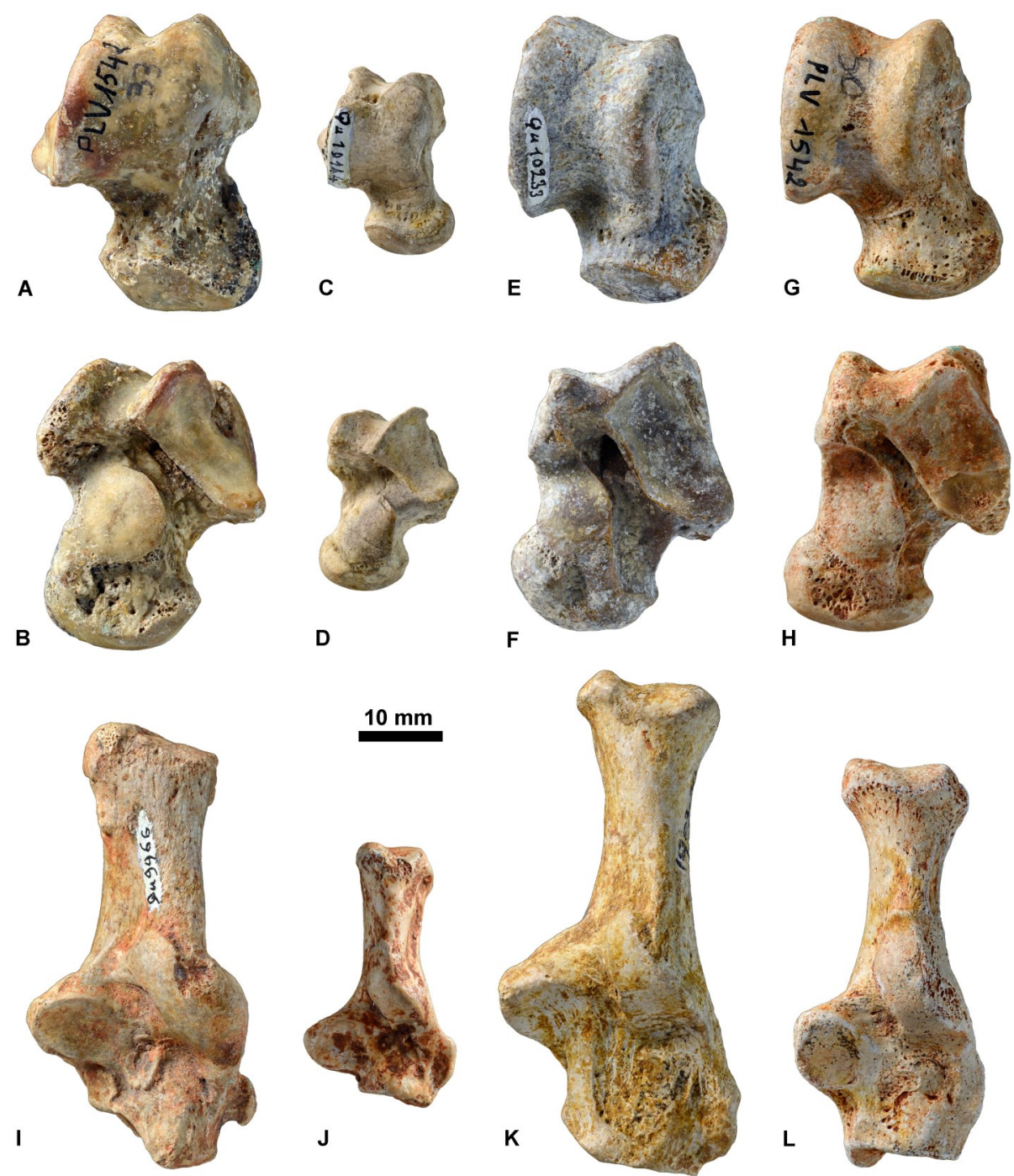

Figure 11. Astragali (A, C, E, G in dorsal view and $\mathrm{B}, \mathrm{D}, \mathrm{F}, \mathrm{H}$ in ventral view) and calcanei (in dorsal view; I-L) housed at ULiège, KU Leuven, and MNHN. Hyaenodonta: A-B, KUL.PLV1542_1; I, MNHN.F. Qu9966. 'Miacidae': C-D, MNHN.F.Qu10144; J, MNHN.F. Qu10375. Nimravidae: E-F, MNHN.F.Qu10233; K, MNHN. Qu10045. Amphicyonidae: G-H, KUL.PLV1542_2; L, ULg.PA. 17170.

\subsection{The complex taxonomy of Cynodictis}

recognize four groups of fossils in the collections of the Belgian institutions: a Priabonian (MP17a-MP20) group (ULiège, KU Leuven), a lower to middle Rupelian (MP21-MP23) group (ULiège, RBINS), a middle to upper Rupelian (MP23-MP25) group (KU Leuven), and an upper Chattian (MP28-MP30) group (ULiège, KU Leuven, RBINS). Among this last group, the fossils are probably from localities close to MP28. Indeed, in the Quercy region, the upper Chattian is mainly represented by faunas close to the MP28 reference fauna (Pech du Fraysse); the faunas from the Quercy region that are similar to those from the MP29 (Rickenbach) and MP30 (Coderet) reference levels are very rare (Sigé et al., 1991; Astruc et al., 2003).

This clarification of the biostratigraphic ranges increases the scientific value of the studied Quercy collections. We hope our study will foster similar analyses of the other mammalian clades from the Quercy Phosphorites (e.g., artiodactyls, rodents) housed in Belgium and elsewhere, to refine the biostratigraphic ranges proposed herein. This, in turn, will augment their utility for further studies incorporating Paleogene mammals, as the current uncertainty of the precise MP level for most specimens resulted in deletion of these specimens from biostratigraphic analyses. In the long term, these collections could provide new information on the evolution of the European mammals during crucial periods such as the 'Grande Coupure' and the 'Microbunodon Event'.
The richness of the Belgian collections helps quantifying the size and morphological variability of the Paleogene carnivorous mammals. Our analysis of the abundant Cynodictis suggest the presence of four taxa: C. lacustris lacustris, C. lacustris intermedius, $C$. longirostris, and $C$. exilis (following the systematic classification proposed by Kotsakis, 1980). We also recognize one specimen in the collection of the KU Leuven (KUL.PLV578) that possibly represents 'Cynodictis' palmidens. The four taxa referred to as Cynodictis are hardly discriminable based on size, and, moreover, the morphology of their respective premolars and molars are closely similar (Bonis, 1978).

Comparison of the length and width of the $\mathrm{p} 4, \mathrm{~m} 1$, and $\mathrm{m} 2$ (Fig. 10A; Table 5) illustrates the difficulty to discriminate the species only based on size data. The m1s of Cynodictis exilis appear to be shorter and narrower than those of the other Cynodictis species, but this is not the case when looking at the $\mathrm{m} 2 \mathrm{~s}$. The dentaries of this taxon are also less deep than those of the other taxa (Table 5). We speculate that the low height of the dentary could result from sexual dimorphism, the specimens of C. exilis being females. Solé et al. (2014b) described similar differences in the height of the dentary between the males and females among the 'miacid' Dormaalocyon. However, the other main character that distinguishes males from females-the presence of diastemata between $\mathrm{p} 1, \mathrm{p} 2$, and $\mathrm{p} 3$ - is not observed when comparing the specimens of $C$. exilis with those of $C$. 
Table 5. Length and width (observed range, mean, and number of specimens) of the p4, m1, and m2 of the Cynodictis species and 'Cynodictis' palmidens based on the specimens housed in the Belgian collections.

\begin{tabular}{|c|c|c|c|c|c|}
\hline & $\begin{array}{l}\text { Cynodictis } \\
\text { exilis }\end{array}$ & $\begin{array}{c}\text { Cynodictis lacustris } \\
\text { intermedius }\end{array}$ & $\begin{array}{c}\text { Cynodictis lacustris } \\
\text { lacustris }\end{array}$ & $\begin{array}{l}\text { Cynodictis } \\
\text { longirostris }\end{array}$ & $\begin{array}{l}\text { 'Cynodictis' } \\
\text { palmidens }\end{array}$ \\
\hline p4 length & $\begin{array}{l}6.08-7.21 \\
6.37(n=5)\end{array}$ & $\begin{array}{c}7.02-9.14 \\
7.96(\mathrm{n}=12)\end{array}$ & $\begin{array}{l}6.32-8.10 \\
7.44(n=9)\end{array}$ & $\begin{array}{l}7.84-8.64 \\
8.26(\mathrm{n}=5)\end{array}$ & - \\
\hline p4 width & $\begin{array}{c}2.35-2.74 \\
2.54(\mathrm{n}=2.5)\end{array}$ & $\begin{array}{c}3.09-3.65 \\
3.35(n=12)\end{array}$ & $\begin{array}{l}2.86-3.90 \\
3.28(\mathrm{n}=9)\end{array}$ & $\begin{array}{l}3.51-4.03 \\
3.76(n=5)\end{array}$ & - \\
\hline m1 length & $\begin{array}{l}7.79-9.07 \\
8.51(\mathrm{n}=8)\end{array}$ & $\begin{array}{c}9.35-11.39 \\
10.33(\mathrm{n}=22)\end{array}$ & $\begin{array}{c}8.99-10.90 \\
10.19(\mathrm{n}=19)\end{array}$ & $\begin{array}{l}10.54-12.25 \\
11.16(n=7)\end{array}$ & $12.56(\mathrm{n}=1)$ \\
\hline m1 width & $\begin{array}{l}3.79-4.92 \\
4.31(\mathrm{n}=8)\end{array}$ & $\begin{array}{c}4.8-6.26 \\
5.37(n=22)\end{array}$ & $\begin{array}{c}4.60-5.66 \\
5.26(n=19)\end{array}$ & $\begin{array}{l}5.39-6.72 \\
5.92(n=7)\end{array}$ & $6.14(\mathrm{n}=1)$ \\
\hline $\mathrm{m} 2$ length & $\begin{array}{l}4.34-5.19 \\
4.9(n=4)\end{array}$ & $\begin{array}{c}3.8-6.06 \\
5.39(n=13)\end{array}$ & $\begin{array}{l}4.57-6.18 \\
5.5(n=11)\end{array}$ & $6.03(\mathrm{n}=1)$ & $5.89(\mathrm{n}=1)$ \\
\hline m2 width & $\begin{array}{l}2.75-3.63 \\
3.16(n=4)\end{array}$ & $\begin{array}{l}3.07-4.09 \\
3.5(n=13)\end{array}$ & $\begin{array}{c}3.15-4.08 \\
3.56(n=11)\end{array}$ & $3.82(\mathrm{n}=1)$ & $3.96(n=1)$ \\
\hline Dentary depth & $\begin{array}{l}9.01-12.97 \\
9.88(\mathrm{n}=8)\end{array}$ & $\begin{array}{c}9.19-13.65 \\
11.68(\mathrm{n}=19)\end{array}$ & $\begin{array}{c}9.27-16.06 \\
12.72(\mathrm{n}=17)\end{array}$ & $\begin{array}{l}12.56-15.94 \\
13.62(\mathrm{n}=7)\end{array}$ & $14.98(\mathrm{n}=1)$ \\
\hline
\end{tabular}

lacustris. Moreover, as indicated above, the m1s of $C$. exilis are clearly shorter than those of $C$. lacustris.

'Cynodictis' palmidens has a $\mathrm{ml}$ that is longer and wider than the Cynodictis species (Fig. 10A). Because the size of its $\mathrm{m} 2$ is similar to those of the $\mathrm{m} 2 \mathrm{~s}$ of the Cynodictis species (Fig. $10 \mathrm{~A}$ ), it is clear that this taxon is characterized by an increase of the $\mathrm{m} 1$ relative to the $\mathrm{m} 2$ and $\mathrm{m} 3$; its case is thus the opposite of that of $C$. exilis. The three other taxa of Cynodictis $(C$. lacustris intermedius, C. lacustris lacustris, C. longirostris) are poorly separated based on size (Fig. 10A; Table 5). However, the m1s of $C$. longirostris are among the longest and widest ones of our sample (except that of 'C.' palmidens). Our PCA corroborates these results: $C$. exilis is clearly dissociated from the other taxa, and, $C$. longirostris could also be separated. The taxa $C$. lacustris lacustris and C. lacustris intermedius are poorly discriminated by this analysis.

The large size of ' $C$.' palmidens, as well as the relatively small size of its $\mathrm{m} 2$, supports the observations of Bonis (1978) and Kotsakis (1980), who regarded ' $C$.' palmidens as a potentially distinct genus. The small size of $C$. exilis regarding the other Cynodictis taxa supports its originality and its specific status. The validity of $C$. longirostris appears fairly robust as well; even if the specimens are close in size to those of $C$. lacustris lacustris and C. lacustris intermedius, they differ by a more distally located metaconid on $\mathrm{m} 1$, resulting in a more open trigonid basin, and by a talonid that is mesiodistally and transversally shortened and less deep.

The main disagreement between Bonis (1978) and Kotsakis (1980) on the systematics of the amphicyonid Cynodictis concerns C. lacustris lacustris and C. lacustris intermedius: Bonis (1978) considered that they represent two distinct species, while Kotsakis (1980) proposed to merge them in the same species (C. intermedius being a subspecies of $C$. lacustris: $C$. lacustris intermedius). Our observations support this statement. Based on our study of the specimens housed in the Belgian institutions, we thus support the proposal of Kotsakis (1980) indicating that these taxa might be regarded as two subspecies.

\subsection{Tarsal bones and other postcranial elements}

Another unusual aspect of the Belgian collections of fossils from the Quercy Phosphorites is the presence of numerous postcranial elements. Regrettably, these elements are difficult to determine when found isolated. However, as demonstrated by Coillot et al.
(2013), based on fossils from the Belgian locality of Dormaal (Ypresian, reference locality of MP7), it is possible to determine postcranial isolated elements by using their morphology, relative size, and relative abundance compared to that of the dental elements. Our study on the tarsal elements supports the possibility to identify postcranial elements, at least at the family level. Moreover, the estimation of the body masses based on both the dental and postcranial elements can allow to refine these determinations (e.g., genus or species level).

Applying the same method to the humeri, ulnas, femurs, tibiae, and innominates housed in the Belgian paleontological collections (Figs 12-13) could yield more precise results. However, it is important to keep in mind that morphofunctional convergence (such as locomotory mode) might bias the identification of isolated postcranial elements (Maynard Smith \& Savage, 1955; Szalay, 1994; Hildebrand, 1995).

In turn, determining postcranial bones is crucial because it can provide data on the locomotion and ecology of Paleogene mammals, which are generally poorly known. For instance, based on the tarsal bones from the Quercy Phosphorites housed in Belgian collections and in the MNHN, Fournier et al. (2020) reconstructed the locomotion (i.e., arboreal, terrestrial) and the posture (i.e., plantigrade, semi-digitigrade, digitigrade) of selected European amphicyonids. Moreover, having data on the locomotion of the extinct mammals adds another layer of information to the reconstruction of the paleoenvironments and their evolution through time and space.

\section{Conclusions}

We determined the fossil carnivorous mammals from the Quercy Phosphorites housed in collections in Belgian institutions; some of these assemblages have never been assessed in the past. In addition to a faunal list and an updated taxonomy, we used the available biostratigraphic ranges of the recorded taxa to reconstruct the original stratigraphic ranges covered by the Belgian collections: the collections at ULiège and KU Leuven universities cover the Priabonian, Rupelian, and late Chattian (most probably close to MP28 reference fauna; ca. 24.8-24 Ma), whereas the old and recent Quercy collections of the RBINS only cover the Rupelian and Chattian.

This assessment also revealed a number of peculiarities in the Belgian collections of carnivorous mammals, notably the presence of abundant dental material and, more importantly, 

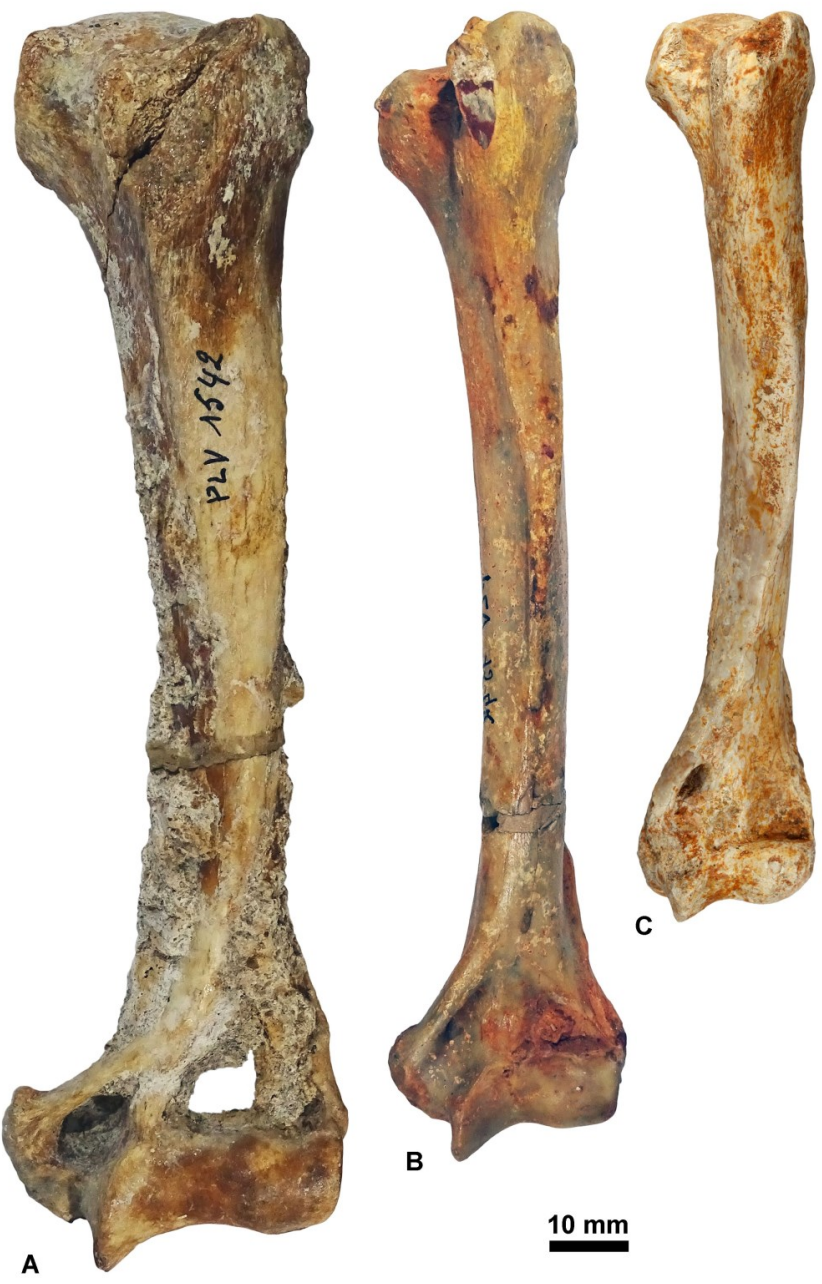

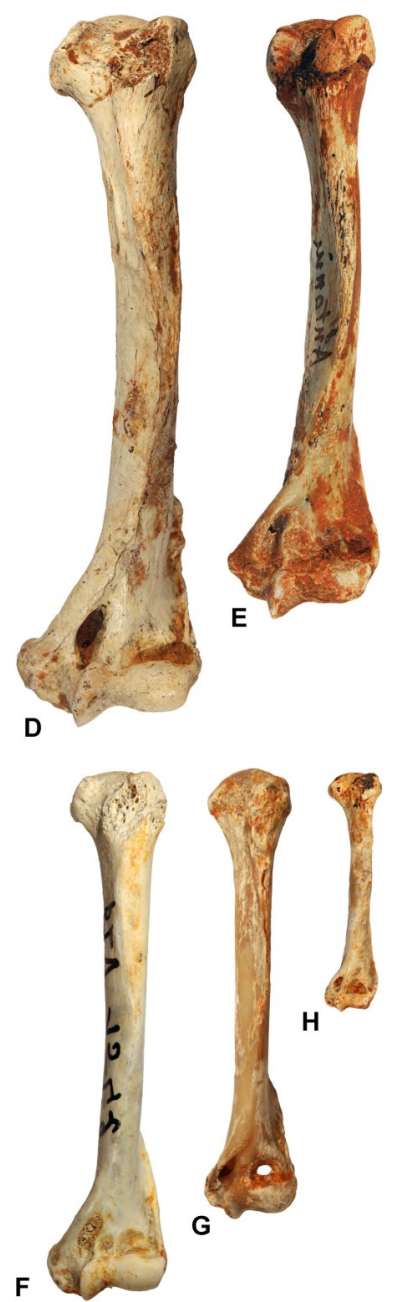

Figure 12. Humeri housed at ULiège and KU Leuven in anterior view. A, KUL.PLV1542 3; B, KUL.PLV1542 4; C, KUL. PLV1542_5; D, KUL.PLV1542_6; E, KUL.PLV1542_7; F, KUL. PLV1542 8; G, ULg.PA.17192; H, ULg.PA.17270_8. Reversed views: $\mathrm{B}, \mathrm{E}, \mathrm{F}$, and $\mathrm{H}$. , Upper scale: A-E; lower scale: F-H. postcranial elements, which opens interesting perspectives on the ecology of these ancient mammals at a time of major climatic and faunal changes.

\section{Acknowledgments}

Femke Augustijns (KU Leuven) and Cécilia Cousin (RBINS) are gratefully thanked for their help with the digitization of the collections and for recovering of data concerning the origin of their respective collections. We are grateful to Nathan Vallée Gillette (RBINS) and Lilian Caze (MNHN) for photographing the fossils. We thank Bastien Mennecart (Natural History Museum Basel) for determination of several of the Quercy Phosphorites Formation artiodactyls housed in the RBINS collection. Finally, we warmly thank the two reviewers, Lars Werdelin and one anonymous reviewer, for their constructive comments that greatly improved this manuscript. This work was financially supported by projects Brain Pioneer BR/175/PI/ CARNAGES and Brain Network BR/121/A3/ PALEURAFRICA of the Belgian Science Policy Office.

\section{References}

Astruc, J.G., Hugueney, M., Escarguel, G., Legendre, S., Rage, J.-C., Simon-Coiçon, R., Sudre, J. \& Sigé, B., 2003. Puycelci, a new vertebrate-bearing locality in the Aquitaine molassic basin. Density and continuity of the Paleogene biochronologic record in the Quercy and peripheral basins area. Geobios, 36, 629-640. https:// doi.org/10.1016/j.geobios.2003.01.001

Baylac, M. \& Friess, M. 2005. Fourier descriptors, Procrustes superimposition, and data dimensionality: an example of cranial shape analysis in modern human populations. In Slice, D.E. (ed.), Modern Morphometrics in Physical Anthropology. Kluwer Academic/Plenum Publishers, New York, 145-165. https:// doi.org/10.1007/0-387-27614-9 6

BiochroM'97, 1997. Tableaux de corrélations et synthèses. In Aguilar, J.-P., Legendre, S. \& Michaux, J. (eds), Actes du colloque international de biostratigraphie BiochroM'97. Mémoires et Travaux de l'Ecole Pratique des Hautes Etudes, Institut de Montpellier, 21, 769-805.

Blondel, C., 2001. The Eocene-Oligocene ungulates from Western Europe and their environment. Palaeogeography, Palaeoclimatology, Palaeoecology, 168, 125-139. https:// doi.org/10.1016/S0031-0182(00)00252-2

Bonis, L. de, 1978. La poche à phosphate de Ste-Neboule (Lot) et sa faune de vertébrés du Ludien supérieur. 12. - Fissipèdes (Carnivores). Palaeovertebrata, 8, 301-311.

Bonis, L. de, 2011. A new species of Adelpharctos (Mammalia, Carnivora, Ursidae) from the late Oligocene of the "Phosphorites du Quercy" (France). Estudios Geológicos, 67, 179-186. https:// doi.org/10.3989/egeol.40553.181

Bonis, L. de, 2013. Ursidae (Mammalia, Carnivora) from the Late Oligocene of the "Phosphorites du Quercy" (France) and a reappraisal of the genus Cephalogale Geoffroy, 1862. Geodiversitas, 35, 787-814. https://doi.org/10.5252/g2013n4a4

Bonis, L. de, Crochet, J.-Y., Rage, J.-C., Sigé, B., Sudre, J. \& VianeyLiaud, M., 1973. Nouvelles faunes de vertébrés oligocènes des Phosphorites du Quercy. Bulletin du Muséum National d'Histoire Naturelle, Série 3, 174, 105-113.

Bravard, A. \& Pomel, A., 1850. Notice sur les ossements fossiles de La Débruge près d'Apt. Mercure Aptésien, Paris, 8 p.

Cifelli, R.L., 1983. Eutherian tarsals from the late Paleocene of Brazil. American Museum Novitates, 2761, 1-31. 


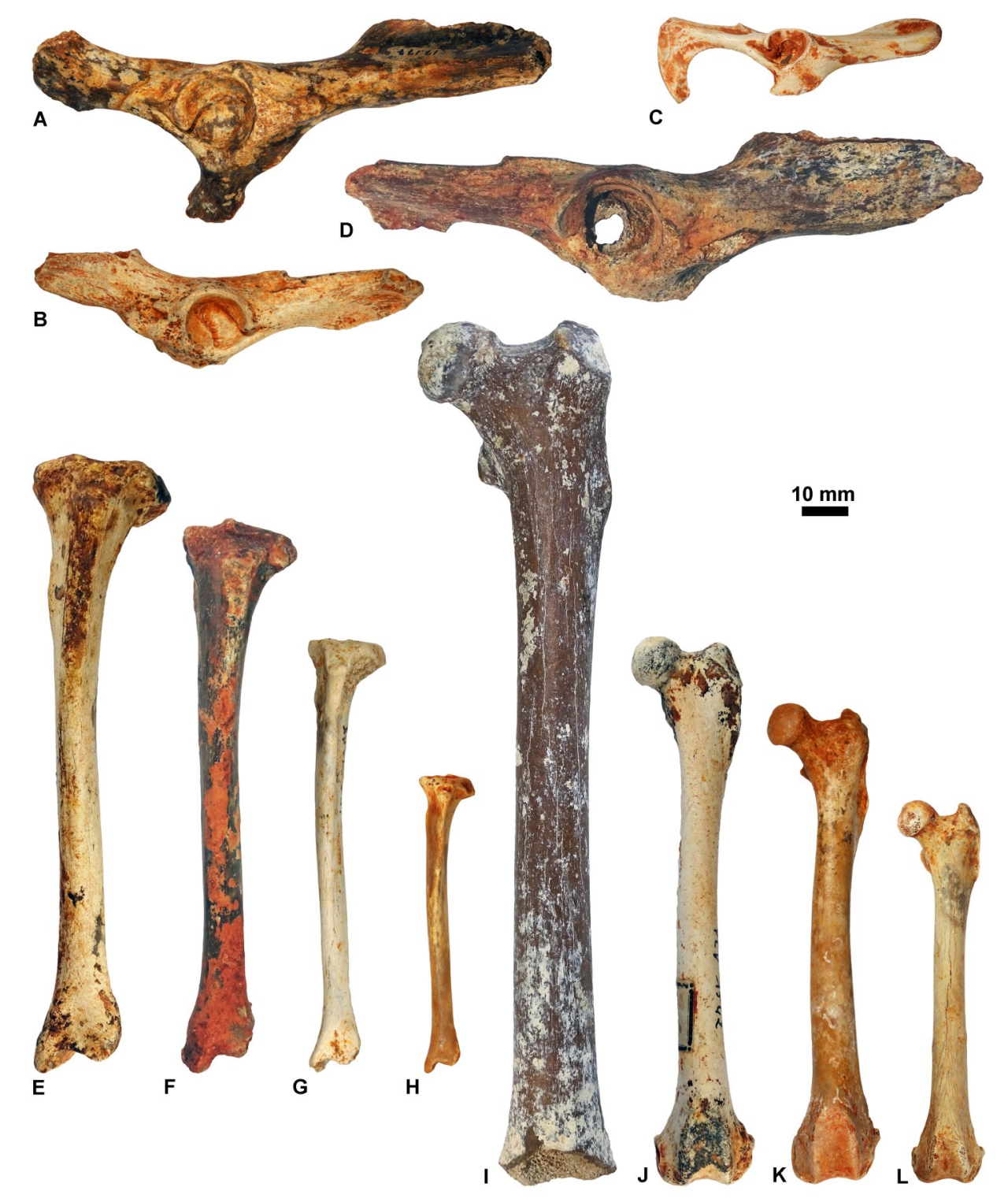

Figure 13. Innominates (in lateral view; A-D), tibias (in anterior view; E-H), and femurs (in anterior view; I-L) housed at ULiège and KU Leuven. Reversed views: $G$ and I. A, ULg.PA.17177 1; B, ULg.PA. 17177_2; C, ULg.PA.17177_3; D, ULg.PA.17177 4; E, KUL.PLV 1542_9; F, KUL.PLV1542_10; G, KUL.PLV1542_11; H, KUL. PLV1542_12; I, KUL.PLV 1542 13; J, KUL.PLV1542 14; K, KUL.PLV1542_15; L, KUL. PLV1542_16.

Claude, J., 2013. Log-shape ratios, Procrustes superimposition, elliptic Fourier analysis: three worked examples in $R$. Hystrix. Italian Journal of Mammalogy, 24, 94-102.

Coillot, T., Smith, R., Gigase, P. \& Smith, T., 2013. Tarsal diversity in the earliest Eocene mammal fauna of Dormaal, Belgium. Geologica Belgica, 16, 274-283.

Escarguel, G. \& Legendre, S., 2006. New methods for analyzing deeptime meta-community dynamics and their application to the Paleogene mammals from the Quercy and Limagne area (Massif Central, France). Strata Série 1, 13, 245-273.

Escarguel, G., Legendre S. \& Sigé, B., 2008. Unearthing deep-time biodiversity changes: The Palaeogene mammalian metacommunity of the Quercy and Limagne area (Massif Central, France). Comptes Rendus Geoscience, 340, 602-614. https://doi.org/10.1016/ j.crte.2007.11.005

Fabre, A.-C., Cornette, R., Huyghe, K., Andrade, D.V. \& Herrel, A., 2014. Linear versus geometric morphometric approaches for the analysis of head shape dimorphism in lizards. Journal of Morphology, 275, 1016-1026. https://doi.org/10.1002/jmor.20278

Filhol, H., 1872. Sur les Carnivores et les Chéiroptères dont on trouve les débris fossiles dans les gisements de Phosphates de Caylux, Frejols et Concots. Comptes Rendus de l'Académie des Sciences, $75,92-94$.

Filhol, H., 1876/1877. Recherches sur les phosphorites du Quercy. Annales des Sciences géologiques, 7-8, 1-558.

Filhol, H., 1879/1880. Etude des mammifères fossiles de Saint-Gérandle-Puy (Allier). Annales des Sciences géologiques, 10, 1-252 \& 11, $1-86$.

Filhol, H., 1881, Etude des mammifères fossiles de Ronzon (HauteLoire). Annales des Sciences géologiques, 12, 1-270.
Flynn, J.J., Finarelli, J.A. \& Spaulding, M., 2010. Phylogeny of the Carnivora and Carnivoramorpha, and the use of the fossil record to enhance understanding of evolutionary transformations. In Goswami, A. \& Friscia, A. (eds), Carnivoran Evolution: New Views on Phylogeny, Form, and Function. Cambridge University Press, Cambridge, 25-63. https://doi.org/10.1017/ CBO9781139193436.003

Fournier, M., Ladevèze, S., Le Verger, K., Fischer, V., Speijer, R.P. \& Solé, F., 2020. On the morphology of the astragalus and calcaneus of the amphicyonids (Carnivora, Mammalia) from the Paleogene of Europe; implications on the ecology of the European bear-dogs. Geodiversitas, 42, 305-325. https://doi.org/10.5252/ geodiversitas2020v42a18

Hartenberger, J.-L., 1987. Modalité des extinctions et apparitions chez les mammifères du Paléogène d'Europe. Mémoire de la Société Géologique de France, N.S., 150, 133-143.

Hildebrand, M., 1995. Analysis of Vertebrate Structure, $4^{\text {th }}$ ed. Wiley, New York, $657 \mathrm{p}$.

Kotsakis, T., 1980. Revisione sistematica e distribuzione stratigrafica e geografica del genere Cynodictis Bravard \& Pomel (Carnivora, Mammalia). Bollettino della Societa Paleontologica Italiana, 19, 259-273.

Lange-Badré, B., 1979. Les Créodontes (Mammalia) d'Europe occidentale de l'Éocène supérieur à l'Oligocène supérieur. Mémoires du muséum national d'histoire naturelle, Série $\mathrm{C}$, Sciences de la terre, 42, 1-249.

Lange-Badré, B., 1995. Le Garouillas et les sites contemporains (Oligocène, MP 25) des Phosphorites du Quercy (Lot, Tarn-etGaronne, France) et leurs faunes de vertébrés. 6. Créodontes. Palaeontographica Abteilung A, 236, 125-133. 
Legendre, S., 1989. Les communautés de mammifères du Paléogène (Éocène supérieur et Oligocène) d'Europe occidentale: structures, milieux et évolution. Münchner Geowissenschaftliche Abhandlungen, Reihe A, Geologie und Paläontologie, 16, 1-110.

Legendre, S. \& Hartenberger, J.-L., 1992. Evolution of mammalian faunas in Europe during the Eocene and Oligocene. In Prothero, D.R. \& Berggren, W.A. (eds), Eocene-Oligocene Climatic and Biotic Evolution. Princeton University Press, Princeton, NJ, 516528. https://doi.org/10.1515/9781400862924.516

Legendre, S. \& Lévêque, F., 1997. Etalonnage de l'échelle biochronologique mammalienne du Paléogène d'Europe occidentale : vers une intégration à l'échelle globale. In Aguilar, J.P., Legendre, S. \& Michaux, J. (eds), Actes du colloque international de biostratigraphie BiochroM'97. Mémoires et Travaux de l'Ecole Pratique des Hautes Etudes, Institut de Montpellier, 21, 461-474.

Legendre, S. \& Marandat, B., 1986. Les phosphorites du Quercy : l'histoire des faunes fossiles de mammifères. Recherches sur les karsts du Quercy et du sud-ouest de la France, Commission Scientifique Midi-Pyrenées, Comité de Spéléologie Régional (F.F.S.), 53-60

Legendre, S., Crochet, J.-Y., Godinot, M., Hartenberger, J.-L., Marandat, B., Rémy, J.A., Sigé, B., Sudre, J. \& Vianey-Liaud, M., 1991. Evolution de la diversité des faunes de mammifères d'Europe occidentale au Paléogène (MP 11 à MP 30). Bulletin de la Société Géologique de France, 162, 867-874. https://doi.org/10.2113/ gssgfbull.162.5.867

Legendre, S., Marandat, B., Sigé, B., Crochet, J.-Y., Godinot, M., Hartenberger, J.-L., Sudre, J., Vianey-Liaud, M., Muratet, B. \& Astruc, J.-G., 1992. La faune de mammifères de Vielase (phosphorites du Quercy, Sud de la France) : preuve paléontologique d'une karstification du Quercy dès l'Eocène inférieur. Neues Jahrbuch für Geologie und Paläontologie Monatshefte, $\quad 7, \quad 414-428 . \quad$ https://doi.org/10.1127/ njgpm/1992/1992/414

Maitre, E., 2014. Western European middle Eocene to early Oligocene Chiroptera: systematics, phylogeny and palaeoecology based on new material from the Quercy (France). Swiss Journal of Palaeontology, 133, 141-242. https://doi.org/10.1007/s13358-0140069-3

Maitre, E., Hugueney, M., Astruc, J.G., Crochet, J.-Y., Escarguel, G., Godinot, M., Legendre, S., Marandat, B., Mourer-Chauviré, C., Rage, J.-C., Rémy, J.A., Simon-Coinçon, R., Sudre, J., Valette, P. \& Sigé, B., 2006. Huit nouvelles faunes éocènes et oligocènes des Phosphorites du Quercy. Strata, Série 1, 13, 113-127.

Maitre, E., Escarguel, G. \& Sigé, B., 2008. Amphilemuridae et autres Lipotyphla éocènes d'Europe occidentale, nouvelles données, systématique et phylogénie. Palaeontographica, 283, 35-82. https:// doi.org/10.1127/pala/283/2008/35

Maynard Smith, J. \& Savage, R.J.G., 1955. Some locomotory adaptations in mammals. Journal of the Linnean Society, 42, 602622. https://doi.org/10.1111/j.1096-3642.1956.tb02220.x

Mennecart, B., 2015. The European ruminants during the 'Microbunodon Event' (MP28, Latest Oligocene): Impact of climate changes and faunal event on the ruminant evolution. PLoS ONE, 10 (2), e0116830. https://doi.org/10.1371/journal.pone.0116830

Morlo, M., 1999. Niche structure and evolution in creodont (Mammalia) faunas of the European and North American Eocene. Geobios, 32, 297-305. https://doi.org/10.1016/S0016-6995(99)80043-6

Morlo, M. \& Peigné, S., 2010. Molecular and morphological evidence for Ailuridae and a review of its genera. In Goswami, A. \& Friscia, A. (eds), Carnivoran Evolution New Views on Phylogeny, Form and Function. Cambridge University Press, Cambridge, 92-140. https://doi.org/10.1017/CBO9781139193436.005

Mosimann, J.E. \& James, F.C., 1979. New statistical methods for allometry with application to Florida redwinged blackbirds. Evolution, 33, 444-459. https://doi.org/10.1111/j.15585646.1979.tb04697.x

Peigné, S., 2000. Systématique et évolution des Feliformia (Mammalia, Carnivora) du paléogène d'Eurasie. Unpublished Ph.D. Thesis, Université de Poitiers, Poitiers, 1-396.

Porto, A., Shirai, L. T., de Oliveira, F. B. \& Marroig, G., 2013. Size variation, growth strategies, and the evolution of modularity in the mammalian skull. Evolution, 67, 3305-3322. https:// doi.org/10.1111/evo.12177

Rage, J.-C., 2006. The lower vertebrates from the Eocene and Oligocene of the Phosphorites du Quercy (France): an overview. Strata, Série $1,13,161-173$.

Rémy, J.-A., Crochet, J.-Y., Sigé, B., Sudre, J., Bonis, L. de, VianeyLiaud, M., Godinot, M., Hartenberger, J.-L., Lange-Badré, B. \& Comte, B., 1987. Biochronologie des phosphorites du Quercy: mise à jour des listes fauniques et nouveaux gisements de mammifères fossiles. Münchner Geowissenschaftliche Abhandlungen, Reihe A, Geologie und Paläontologie, 10, 169-188.

Renault, P., Guillot, P.L., Lefavrais-Raymond, A., Seronie-Vivien, M.R., Cavaillé, A. \& Clottes, J., 1978. Géologie du Quercy. Les suppléments de Quercy Recherche, Série Etudes et Travaux, 4, 1111.

Scherler, L., Mennecart, B., Hiard, F. \& Becker, D., 2013. Evolution of terrestrial hoofed-mammals during the Oligocene-Miocene transition in Europe. Swiss Journal of Geosciences, 106, 349-369. https://doi.org/10.1007/s00015-013-0140-x

Schmidt-Kittler, N., Godinot, M., Franzen, J.L., Hooker, J.J., Legendre, S. Brunet, M. \& Vianey-Liaud, M., 1987. European reference levels and correlation tables. Münchner Geowissenschaftliche Abhandlungen, Reihe A, Geologie und Paläontologie, 10, 13-31.

Sigé, B., Aguilar, J.-P., Marandat, B. \& Astruc, J.G., 1991. Extension au Miocène inférieur des remplissages phosphatés du Quercy. La faune de vertébrés de Crémat (Lot, France). Geobios, 24, 497-502. https://doi.org/10.1016/S0016-6995(06)80251-2

Solé, F., 2014. New carnivoraforms from the early Eocene of Europe and their bearing on the evolution of the Carnivoraformes. Palaeontology, 57, 963-978. https://doi.org/10.1111/pala.12097

Solé, F., Falconnet, J. \& Laurent, Y., 2014a. New proviverrines (Hyaenodontida) from the early Eocene of Europe; phylogeny and ecological evolution of the Proviverrinae. Zoological Journal of the Linnean Society, 171, 878-917. https://doi.org/10.1111/zoj.12155

Solé, F., Smith, R., Coillot, T., De Bast, E. \& Smith, T., 2014b. Dental and tarsal anatomy of "Miacis" latouri and a phylogenetic analysis of the earliest carnivoraforms (Mammalia, Carnivoramorpha). Journal of Vertebrate Paleontology, 34, 1-21. https:// doi.org/10.1080/02724634.2013.793195

Springhorn, R., 1977. Revision of Paleogene European Amphicyonidae. Palaeontographica, 158, 26-113.

Stehlin, H.G., 1909. Remarques sur les faunules de mammifères des couches éocènes et oligocènes du Bassin de Paris. Bulletin de la Société Géologique de France, 9, 488-520.

Szalay, F.S., 1994. Evolutionary History of the Marsupials and an Analysis of Osteological Characters. Cambridge University Press, New York, 481 p. https://doi.org/10.1017/CBO9780511565571

Teilhard de Chardin, P., 1915. Les carnassiers des phosphorites du Quercy. Annales de Paléontologie, 9, 103-191.

Tsubamoto, T., 2014. Estimating body mass from the astragalus in mammals. Acta Palaeontologica Polonica, 59, 259-265. http:// dx.doi.org/10.4202/app.2011.0067

Vandenberghe, N., Hilgen, F.J. \& Speijer, R.P., 2012. The Paleogene Period. In: Gradstein, F.M., Ogg, J.G., Schmitz, M.D. \& Ogg, G.M. (eds), The Geologic Time Scale 2012. Elsevier, Amsterdam, 855921. https://doi.org/10.1016/B978-0-444-59425-9.00028-7

Van Valkenburgh, B.V., 1990. Skeletal and dental predictors of body mass in carnivores. In Damuth, J. \& MacFadden, B.J. (eds), Body Size in Mammalian Paleobiology: Estimation and Biological Implications. Cambridge University Press, Cambridge, 181-206.

Vianey-Liaud, M. \& Marivaux, L., 2017. Autopsie d'une radiation adaptative : Phylogénie des Theridomorpha, rongeurs endémiques du Paléogène d'Europe - histoire, dynamique évolutive et intérêt biochronologique. Palaeovertebrata, 40, 1-68. https:// doi.org/10.18563/pv.40.3.e1

Zachos, J.C., Pagani, M., Sloan, L., Thomas, E. \& Billups, K., 2001. Trends, rhythms, and aberrations in global climate $65 \mathrm{Ma}$ to present. Science, 292, 686-693. https://doi.org/10.1126/ science. 1059412

Zachos, J.C, Dickens, G.R. \& Zeebe, R.E., 2008. An early Cenozoic perspective on greenhouse warming and carbon-cycle dynamics. Nature, 451, 279-283. https://doi.org/10.1038/nature06588

Manuscript received 24.01.2020, accepted in revised form 10.06.2020, available online 25.08.2020.

Supplementary data for this paper are available online at https:// doi.org/10.20341/gb.2020.006. 